\title{
Report of the Korean Association of External Quality Assessment Service on Clinical Mycobacteriology (2017-2018)
}

Soyoun Shin and Seok Ho Hong Laboratory Medicine Center, The Korean Institute of Tuberculosis, Cheongju, Korea

Corresponding author: Soyoun Shin The Korean Institute of Tuberculosis, 168-5 Osongsaengmyeong 4-ro, Osong-eup, Heungdeok-gu, Cheongju 28158, Korea E-mail: leukoso@hanmail.net
Rapid and correct diagnosis is essential for national tuberculosis (TB) control. A greater national concern for quality control (QC) of Mycobacterium tuberculosis (MTB) testing is required to improve the proficiency of domestic clinical laboratories using diverse testing protocols in private and public sectors. External quality assessment (EQA) is an important program accompanying internal QC in clinical TB laboratories. In Korea, the EQA program initiated in 2005 by the Korean Association of External Quality Assessment Service (KEQAS) has made remarkable progress in the harmonization of private and public sectors with governmental support since 2011. An integrative TB EQA program led by the KEQAS with financial support from the Korea Centers for Disease Control and Prevention provides optimized EQA materials for both public and private sectors. In 2017, the KEQAS implemented 'The Next-Generation Proficiency Testing Program' equipped with a centralized control system of QC material production and electronic data management, which increased the scale of operating programs from 46 to 54 and recruited 1,700 participants. The TB program was also expanded to provide three times EQA for private laboratories from 2 times a year. For TB EQA programs implemented via the Clinical Microbiology Subcommittee of the KEQAS, survey materials were distributed by sectional orders for tests such as acid-fast bacilli (AFB) smears, AFB culturing and identification, antituberculous drug susceptibility screening, AFB molecular diagnosis, and rapid detection of rifampin and isoniazid resistance. All survey materials were produced by sophisticated manufacturing processes and thoroughly analyzed by various commercial kits, targeted DNA sequencing, and whole-genome sequencing in pre- and post-manufacturing phases for advancement in the EQA program.

(J Lab Med Qual Assur 2019;41:82-104)

Key Words: Tuberculosis, External quality assessement, Proficiency test, Laboratory diagnosis

\section{서론}

2018년 World Health Organization (WHO) global tuberculosis report (23th ed.)에 따르면, 결핵(tuberculosis) 은 에이즈와 더불어 단일 감염체 감염 사망원인이 되는 세계 10 대 전염병 중 하나로, 2017 년도 기준, 결핵 유병률은 1,000 만 명으로 추정되고 있으며, 신환 신고율은 640 만 명이었고, 약 160 만 명이 결핵으로 사망한 것으로 보고되었다[1]. 경제 협력개발기구(Organization for Economic Cooperation and
Development, $\mathrm{OECD}$ ) 가입국들의 10만 명당 결핵환자 수는 평균 13.4명이고, 우리나라 질병관리본부 2018년 결핵환자 신 고현황연보에 따르면, 신고결핵 환자율 및 신환자율은 각각 인 구 10 만 명당 남성 59.8 명과 여성 43.3명으로, $\mathrm{OECD}$ 국가 중 에서 결핵 발생률 및 사망률에 있어 경제규모에 비해 여전히 높은 유병률을 보이고 있다[2]. 2016년부터 시작된 WHO the End TB Strategy'(2015년도 대비, 2030년까지 결핵으로 인 한 사망률을 $90 \%$ 까지, 신환 발생률을 $80 \%$ 까지 낮추고, 결핵 으로 인한 가계부담을 없애는)에 따라 대한민국 정부에서도 


\section{Journal of LABORATORY MEDICINE and QUALITY ASSURANCE}

\section{Soyoun Shin et al • Report on Clinical Mycobacteriology EQA Program}

'결핵안심국가' 계획을 마련하고 대대적인 잠복결핵감염 검진 사업을 시행하는 등 국내 결핵 유병률을 낮추기 위한 각고의 노력이 집중되고 있다[3]. 여러 사람에게 전파할 수 있는 강한 감염력을 가진 '활동성 결핵'을 조기에 진단하고 적절한 치료 가 가능할 수 있도록 하는 것이 답보되어야만 잠복결핵감염검 진 및 치료사업이 보다 의미 있는 정책적 사업이 될 것이며, 이 에 활동성 결핵의 검사실 진단의 정확도를 평가하고 이를 제고 하는 것이 더욱 필요한 시점이라 할 수 있다.

결핵을 진단하기 위해서는 다양한 검사법이 이용되고 있지 만 확진을 위해서는 임상 가검물로부터 균을 검출하거나 분리 해야 한다. 결핵검사는 환자의 진단, 치료반응 평가, 항결핵제 내성 확인에 이용되고 있다.

항산균 도말염색은 결핵균이 산에 저항성이 강한 성질을 이 용하여 carbolfuchsin 성분 염료로 염색 후 산성알코올로 탈색 하는 Ziehl-Neelson법 및 가열과정을 없애고 염료농도를 높인 Kinyoun법이 있으며, 보다 높은 민감도를 보이는 형광염색법 도 쓰이고 있다. 항산균 도말검경은 간편한 검사법으로 쉽고 간편하게 전염력이 높은 결핵균 배균환자를 검출할 수 있어 매 우 중요한 검사이며, 가장 기본적인 검사법으로 대부분의 결핵 고부담 국가에서 도말검사를 이용하여 결핵관리사업을 수행 하고 있다. 도말검경은 가장 기본적인 검사이지만 많은 한계점 이 있다. 비결핵 항산균이나 죽은 결핵균도 검출할 수 있어 임 상적 해석에 주의를 요하며, 민감도가 20\%-80\%로 검체 전처 리와 검사자의 숙련도에 따라 쉽게 영향을 받을 수 있는 검사 로서 외부정도관리프로그램이 매우 중요한 분야라 할 수 있다 [3].

항산균 배양은 결핵진단의 표준검사법으로, 도말 음성 결핵 을 검출할 수 있으며 균종동정과 항결핵제 감수성검사를 위해 서 필요하다. 또한 살아있는 균만 배양이 되므로 치료 중인 환 자의 치료반응을 평가하는데 필수적인 검사이다. 결핵배양에 사용되는 배지는 크게 고체배지와 액체배지가 있다. 계란성분 의 Löwenstein Jensen (LJ) 배지와 Ogawa 배지는 다루기 쉽 고 오염이 적어 전 세계적으로 널리 사용되고 있다. 그러나 고 체배지는 배양기간이 길어 실제 임상진료에는 도움이 되지 못 하는 경우가 많다. 액체배지를 이용할 경우 검출시기를 단축 할 수 있는데, 최근부터 고체, 액체 병행배양의 보험수가가 인 정됨으로써 상품화된 자동배양 감지시스템을 통한 액체배지 의 사용이 크게 늘고 있다. 그러나 고체배지에 비해 검체 오염 률이 높아 액체배양 오염률 관리 및 오염 검체의 처리 등에 대 한 검사실별 질 관리가 중요하다. 국내 - 외 지침에서 도말검경 과 배양검사를 함께 시행할 것을 권고하고 있으나 국내에서는 도말검사만 시행되고 배양검사는 시행되지 않는 경우가 아직
많다. 치료반응을 확인하기 위해서는 추후 배양이 필수적이므 로 낮은 배양의뢰를 시급히 높여야 한다. 또한 비결핵 항산균 의 분리비율이 점차 증가하고 있어 배양을 통해 비결핵 항산균 과 감별이 반드시 필요하다.

항결핵제 감수성검사는 다제내성 환자의 발견과 적합한 처 방을 가능하게 하여 국내 결핵 다제내성률을 파악하여 신약도 입 및 결핵퇴치정책 수립을 위한 중요한 자료를 제공한다.

$\mathrm{WHO}$ 결핵검사실역량강화방안 중 항결핵제 감수성검사의 보편적 시행을 주요 달성 목표로 포함하고 있는 만큼 다제내성 의 신속하고 정확한 검사실 진단의 중요성이 강조되고 있다. 국가 정책 및 진단절차가 항결핵제 감수성검사의 보편적 시행 을 원칙으로 하고 있는지, 세균학적으로 확인된 결핵환자에 서 rifampicin (RIF) 내성 보고율과 RIF 내성인 결핵환자에서 fluoroquinolone과 2차 주사약제에 대한 항균제 감수성검사결 과 보고율을 그 세부지표로 하고 있다[4]. 통상 감수성 시험은 배양법을 이용하기 때문에 4주 정도의 시간이 필요하다. 따라 서 신속하게 결과를 얻기 위해서는 액체배양 기반의 항결핵제 감수성검사나 분자생물학적 검사법이 일부 대체되어 사용되 고 있다. 국내에서는 LJ 배지 기반의 절대농도법을 이용하는 기관이 많으며 액체배양 기반의 감수성 시험을 이용하거나 분 자생물학적 방법을 동시에 수행하는 기관이 늘어나고 있어 이 에 대한 정도관리가 필요하다.

항산균 분자검사는 항산균 균종동정검사와 항산균 신속약 제 감수성검사에 대한 외부정도관리를 시행하고 있다. 항산 균 분자동정검사는 결핵균의 특이유전자를 증폭하여 검출하 기 때문에 도말검사에 비해 민감도가 높고, 시판되는 분자검사 키트의 디자인에 따라 결핵과 비결핵을 감별할 수 있는 장점 이 있다. 또한 2017년 질병관리본부 결핵검사지침 개정에 의 거하여 항산균 분자동정검사는 결핵의심 환자에 한해 초회 1 회 한정 시행에서 매회 시행으로 바뀜에 따라 국내 결핵검사 실프로그램 참여의 증가가 예상된다. 결핵균 신속약제 감수성 검사는 결핵균의 주요 내성 유전자 변이를 검출하는 검사로서 WHO에서도 isoniazid (INH)와 RIF에 대한 신속약제 감수성 검사를 권고하고 있으며, 특히 검체에서 바로 내성을 알 수 있 기 때문에 검사시간을 크게 단축시킬 수 있다. Xpert MTB/ RIF (Cepheid, Sunnyvale, CA, USA)이 대표적이며, 결핵균 $\mathrm{DNA}$ 와 RIF 내성유전자 변이를 동시에 검출하고, 원 검체로 검사를 완료할 수 있는 point-of-care testing 장비로, 검사자 의 수기 조작이 최소화되어 전문인력 수급이 어려운 저개발국 결핵퇴치사업을 위해 적극적으로 설치 및 활용되고 있다. 국내 에서는 실시간 핵산증폭장비를 이용한 결핵동정 및 다제내성 관련 유전자 분석키트, line probe assay (LPA) 등의 다양한 


\section{Journal of LABORATORY MEDICINE and QUALITY ASSURANCE}

Soyoun Shin et al • Report on Clinical Mycobacteriology EQA Program

분자생물학적 기법과 키트들이 상용화되고 있어 외부정도관 리 운영이 보다 광범위하게 실시될 필요성이 있다.

대부분의 결핵검사는 수기검사이기 때문에 검사의 질 관리 가 중요하다. 검사의 질에 영향을 미치는 요인은 많은데, 검사 자의 숙련도, 검사실 시설, 검사량 등이 있다. 검사의 질을 주 기적으로 평가하고 문제점이 발견될 경우 신속하게 해결해야 한다. 그러나 이를 정확하게 평가하는 것은 매우 어려운 과정 이며, 많은 검사실에서 질 관리의 중요성을 간과하고 있다. 부 정확한 검사결과를 보고할 경우 결핵의 추가 확산, 내성결핵의 증가 등 여러 문제가 발생할 수 있기 때문에 $\mathrm{WHO}$ 에서도 결핵 검사실검사의 질 관리의 중요성을 강조하고 있으며 여러 자료 를 제공하고 있다. Quality assurance $(\mathrm{QA})$ 는 검사서비스의 신뢰성과 효율성을 지속적으로 향상시키기 위한 시스템을 말 한다[5]. $\mathrm{WHO}$ 와 국제항결핵연맹에서는 도말검경에 대한 $\mathrm{QA}$ 는 (내부)정도관리(quality control), 외부정도관리(external quality assessment) 그리고 질 향상(quality improvement) 의 세 가지 요소로 구성된다고 정의하고 있다[6]. 이러한 배경 에서 최근 $\mathrm{WHO}$ 에서는 'the End TB Strategy' 이행을 위한 구체적인 결핵검사실 결핵검사실 역량강화방안(framework of indicators and targets for laboratory strengthening under the End TB Strategy, October 2016)을 발표하였는 데, WRD (WHO-recommended rapid diagnosis) 도입을 통 한 신속하고 정확한 결핵검사 접근성 강화, 항산균약제 감수성 검사의 보편적 시행, 검사실검사 질 관리 강화의 세 가지 주제, 총 12 개의 지표에 대하여 2025년까지 구체적인 국가별 결핵검 사의 접근성 및 신뢰도 확보 목표를 제안하고 있다.

검사실검사 질 관리 강화의 부분에는 국내 결핵검사실 외 부정도관리프로그램 운영 및 기관 참여율, 항결핵제 감수성 검사에 대한 외부정도관리 우수기관의 비율, 검사실 인증프 로그램의 운영과 국가별 참조검사실의 ISO (International Organization for Standardization) 인증 여부 등을 평가하는 것으로 되어 있어 결핵 퇴치를 위한 결핵검사실의 역할 및 외 부정도관리의 중요성이 더욱 요구되는 시점이라 할 수 있으며, 이에 따라 대한임상검사정도관리협회는 2017년부터 결핵진단 검사 외부정도관리프로그램을 연 3회로 확대 운영하였다.

\section{재료 및 방법}

\section{1. 항산균 도말검사의 정도관리}

패널 슬라이드는 5 장으로 구성하였으며, 다양한 양성 슬라 이드와 음성 슬라이드를 포함하였다. 결과분석 용이 및 사무적 오류 감소를 위해 대한임상검사정도관리협회의 신빙도조사사
업 결과 입력프로그램을 이용하였으며, 2017년부터 결과 판정 에 있어 현재 국제결핵도말검사의 표준이 되는 $\mathrm{WHO}$ 판정기 준을 일괄 적용하도록 하였다.

검체 선정 및 전처리과정에서 양성 검체의 경우, 2017년 기 준, 양이 많고 불순물이 적으며 집균 처리가 되지 않은 항산균 도말검사에서 $1+, 2+, 3+$ 의 결과를 보이는 양질의 임상 잔 여 검체를 선정해서 $10 \mathrm{~mL}$ 정도로 pooling하여 사용하거나 $3+$ 등급의 결핵양성 객담을 희석하여 제작하였으며, 2018년 에는 병독성이 없는 H37Ra 표준균주(ATCC25177)를 전처리 하여 음성 객담에 희석한 후 각 등급에 적합한 검체를 제작하 였다. 음성 검체는 매회 2 명의 호흡기 증상, 결핵 기왕력, 노출 력 등이 없고, 잠복결핵검사 음성인 건강인 객담을 각 $10 \mathrm{~mL}$ 정도 채취하여 도말검사, 배양검사, 분자검사 검증 후 pooling 하여 사용하였다.

검체 제작과정에서는 슬라이드를 $99 \%$ 알코올에 세척한 후 라벨을 부착하였으며, 모든 슬라이드는 판정등급에 따라 각 기 다른 일정을 통해 제작하여 제작과정에서 발생할 수 있 는 사무적 오류를 줄이고자 하였다. Pooling한 양 - 음성 검체 는 $5 \%$ 페놀로 액화 및 탈오염 처리하였으며, 슬라이드는 판 정등급에 적합한 양·음성 검체로 제조하였다. $3+$ 슬라이드 는 McFarland 탁도 1.0 균주 균질액을 음성 객담에 희석하 여 $\mathrm{WHO}$ 판정기준에 따라 적정 균수를 보이는 객담을 제조한 후 제작하였으며, $1+, 2+$ 슬라이드는 $3+$ 객담과 음성 객담 을 혼합하여 제조하였다. 1 주간 매일 5 개 슬라이드 제작하여 Ziehl-Neelsen 염색방법으로 음성 및 각 등급의 양성 결과를 확인 후 사전 검증하였다. 검증이 완료된 검체는 $10 \mu \mathrm{L}$ 씩 가로 $2 \mathrm{~cm}$ 세로 $1 \mathrm{~cm}$ 로 슬라이드에 도말 후 2 시간, $70^{\circ} \mathrm{C}$ 조건으로 warmer에서 고정하였으며, 제작된 슬라이드 중 20 sets를 무 작위로 선정하여 항산균 염색 후 5-6명의 도말배양검사 담당

Table 1. WHO AFB stain interpretation classification

\begin{tabular}{llll}
\hline \multirow{2}{*}{ WHO } & \multicolumn{3}{c}{ Microscopy system used } \\
\cline { 2 - 4 } & $\begin{array}{c}\text { Bright field } \\
1,000 \times\end{array}$ & $\begin{array}{c}\text { Fluorescence } \\
200 \times\end{array}$ & $\begin{array}{c}\text { Fluorescence } \\
400 \times\end{array}$ \\
\hline Negative & No AFB & No AFB & No AFB \\
Scanty & $1-9 / 100 \mathrm{~F}$ & $1-29 / 30 \mathrm{~F}$ & $1-19 / 40 \mathrm{~F}$ \\
$1+$ & $10-99 / 100 \mathrm{~F}$ & $30-299 / 30 \mathrm{~F}$ & $20-199 / 40 \mathrm{~F}$ \\
$2+$ & $1-10 / \mathrm{F}^{*}$ & $10-100 / \mathrm{F}^{*}$ & $5-50 / \mathrm{F}^{\star}$ \\
$3+$ & $>10 / \mathrm{F}^{*}$ & $>100 / \mathrm{F}^{*}$ & $>50 / \mathrm{F}^{\star}$ \\
\hline
\end{tabular}

Abbreviations: WHO, World Health Organization; AFB, acid-fast bacilli.

${ }^{\star}$ At least 50 fields. 


\section{Journal of LABORATORY MEDICINE and QUALITY ASSURANCE}

Soyoun Shin et al $\bullet$ Report on Clinical Mycobacteriology EQA Program

자가 $\mathrm{WHO}$ 판정기준에 따라 균수와 배경상태를 확인하여 도 말을 검경함으로써 사후검증을 시행하였다(Table 1).

\section{2. 항산균 배양 및 동정검사 정도관리}

참여기관은 배양 양성 시 반드시 감별검사를 실시하며, 배양 결과는 결핵균 배양 양성, 결핵균 배양 음성, 항산균 배양 양성 등으로 구분하여 보고하도록 하였다.

배양 정도관리물질에서 배양된 균주에 대해서는 균종동 정을 실시하도록 하였으며, 정도관리 균주는 $r p o B$ 와 $16 \mathrm{~S}$ $\mathrm{rRNA}(\mathrm{rrs})$ 유전자의 염기서열을 분석하여 동정결과를 재확 인한 후 선정하여 사용하였다. Mycobacterium abscessus, $M$. avium 등 정상인에 상재기회감염을 일으키는 것으로 알려진 nontuberculous mycobacteria (NTM) 균주의 균액을 각각 인공객담에 첨가하여 음성 검체로 사용하였으며, 결과는 검사 실별 시행하는 검사장비 및 키트의 검사수준에 따라 시험 가능 한 수준까지 보고하도록 하였다.

검체 선정과정에서 병독성이 없는 결핵 표준균주 $\mathrm{H} 37 \mathrm{Ra}$ (ATCC25177)를 계대 배양 후 결핵균 양성 균주로 선 정하였으며, M. kansasi (ATCC12478), M. abscessus (ATCC19977), M. avium (ATCC25291), M. fotuitum (ATCC49403), M. intracellurae (ATCC13950) 등의 NTM 표준균주 중 2-3종을 선택하여 NTM 양성 균주로 선정하였 다. Escherichia coli, Enterococcus 등의 상재 오염균은 혈액 한천배지, MacConkey 배지에 계대 배양한 후 음성 객담 첨 가 균주로 선정하였다. 검체 제작과정에서는 $1 \%$ mucin, $0.1 \%$ xanthangum 혼합액을 $100 \mathrm{~mL}$ 제조 후 30초 동안 vortex mixer로 균질화시켜 인공객담을 만든 후 고압증기멸균을 시 행하였다. 멸균된 phosphate-buffered saline (PBS, pH 7.0) 로 균주를 희석하여 McFarland 농도 1.0 균주 균질액을 만든 후 균주 균질액 대 인공객담 4,000배 희석하여 정도관리용 균 주 인공객담을 만들었다. 각 검체별로 $10 \mathrm{~mL}$ 튜브에 $4 \mathrm{~mL}$ 씩

Table 2. Range of drug concentration for minimal inhibition concentration assessment

\begin{tabular}{cc}
\hline Antituberculous drugs & Range of concentration $(\mu \mathrm{g} / \mathrm{mL})$ \\
\hline Isoniazid & $0.05,0.1,0.2,0.4,1.0$ \\
Rifampicin & $10,20,40,80$ \\
Ethambutol & $0.5,1.0,2.0,4.0$ \\
Streptomycin & $1.0,2.0,4.0,8.0,10.0$ \\
Ofloxacin & $0.5,1.0,2.0,4.0$ \\
Kanamycin & $10,20,30.40,80$ \\
Amikacin & $10,20,30,40,80$ \\
\hline
\end{tabular}

분주하여 제공하였으며, 배포 전 제작 검체를 무작위 선정하여 배양검사와 실시간중합효소연쇄반응검사를 시행하여 예상결 과가 일치하면 정도관리물질 균주로 선정하고, 배양결과는 추 후에 확인하여 결과시험서에 기록하였다.

\section{3. 항결핵제 감수성검사 정도관리}

항산균약제 감수성검사 검체는 생물학적 고위험 감염체 이므로 우편 탁송이 아닌 직접 배송을 원칙으로 하였다. 5 개 의 panel strains을 선별하여 대상기관에 발송하였고, 모든 panel strains은 감수성검사를 다시 시행하여 감수성 결과를 확인하였으며, 주요 약제의 최소억제농도(minimal inhibition concentration, MIC)를 측정하며 내성과 연관된 유전변이를 확인하였다. $\mathrm{MIC}$ 측정을 위한 항결핵제 농도범위와 분석유전 자의 종류는 Table 2 그리고 Table 3 과 같다. 분석대상 항결핵 제는 따로 설정하지 않았으며, WHO SRLN (Supranational Reference Laboratory Network)의 외부정도관리 최종결과 와 사전검증결과를 표준검사기준으로 판단하여 전체 결과 중 위양성, 위음성 수를 평가지표로 하였다. 항결핵제로는 $\mathrm{INH}$, $\mathrm{RIF}$, streptomycin, ethambutol을 1차 약제, kanamycin, amikacin, capreomycin을 주사제(injectables)로, ofloxacin, levofloxacin, moxifloxacin을 fluoroquinolone제로 구분하였 다.

검체 선정과정에 있어서는 next generation sequencing을 이용하여 유전특이성을 확인한 $\mathrm{WHO}$ 정도관리 균주의 list 중 패턴이 상이한 그룹별 균주를 5 개 선정 후 배양하여 배양의 질 이 좋은 균주를 이용하여 정도관리 검체를 제작하였다. 1 차 약 제 및 주요 2 차 약제의 내성이 포함될 수 있도록 하며, 필요 한 균주보다 1 개를 더 선정하여 검체를 제작하였고, 광범위 약 제내성균은 제외하였다. 검체 검증과정에 있어서는 고압증기 멸균한 10\% Tween 80으로 대상 균주를 균질화하고 멸균된 $\mathrm{PBS}$ (pH 7.0)로 희석한 다음 McFarland 탁도 1.0 균주 균질 액을 제조하였다. 튜브에 PBS (pH 7.0) $4.5 \mathrm{~mL}$ 을 넣고 균주

Table 3. Genes related to antituberculous drug resistance

\begin{tabular}{ll}
\hline Antituberculous drugs & Genes related to drug resistance \\
\hline Isoniazid & $\operatorname{kat} G, \operatorname{inh} A$, aph $C$ \\
Rifampicin & $r p o B$ \\
Streptomycin & $r p s L$, gidB \\
Ethambutol & $\operatorname{embB}$ \\
Fluoroquinolone & gyr $A$, gyrB \\
Injectables & $16 \mathrm{~s}$ rRA, eis \\
Pyrazinamide & $p n c A$ \\
\hline
\end{tabular}




\section{Journal of LABORATORY MEDICINE and QUALITY ASSURANCE}

\section{Soyoun Shin et al • Report on Clinical Mycobacteriology EQA Program}

균질액을 $0.5 \mathrm{~mL}$ 첨가하여 10 배 희석한 다음 $\mathrm{LJ}$ 배지 절대농 도법을 이용한 항결핵제 감수성검사(M-kit; Korean National tuberculosis Association, Seoul, Korea), MIC로 검증을 진 행하였다. 4 주 배양된 균주를 확인하는 과정에서 대조배지 증 식 $3+$ 이상, PNB (P-nitrobenzoic acid) 배지에서는 증식이 없으며, 약제배지에서 대조배지 증식보다 $1 \%$ 이상인 경우 내 성으로 판정하였다. 정도관리 검체는 배지에 증식한 균주상태 로 제공되었으며, 검증이 완료된 균주를 3 중 생물학적 안전용 기에 밀봉 후 해당 기관에 직접 배송하였다.

\section{4. 항산균 분자동정검사의 정도관리}

항산균 분자동정검사의 정도관리는 대한임상검사정도관리 협회 분자유전분과에서 시행하였으나, 2016년부터 항산균 분 자검사항목으로 분류되어 본 프로그램을 통해 정도관리를 시 행하였다. 2017년도 사업에서 시범 시행한 약양성 검체 검사 를 정식 외부정도관리프로그램에 포함시켜 2018년도 결핵균 동정분자검사 전 회에 걸쳐 시행하였다.

$\mathrm{MTB}$ 표준균주 H37Ra (ATCC25177)를 양성 검체로 선 정하였으며, M. kansasi (ATCC12478), M. abscessus (ATCC19977), M. avium (ATCC25291), M. fotuitum (ATCC49403), M. intracellurae (ATCC13950) 등 NTM 표 준균주 중 1종 선정하여 NTM 검체로 선정하였다.

H37Ra 및 NTM 균주를 계대 배양하여 고압증기 멸균한 $10 \%$ Tween 80으로 균주를 균질화한 후 멸균된 PBS ( $\mathrm{pH}$ 7.0)으로 희석하여 McFarland 탁도 1.0 균주 균질액을 제조 하였다. 제작된 균액을 $100^{\circ} \mathrm{C}$ 항온수조에서 5 분간 비동화한 후 멸균 3차 증류수로 계대 희석하여 단계별 실시간중합효소 연쇄반응검사로 검증하였으며, 가장 많은 참여기관에서 사용 하고 있는 상품화된 키트를 이용하여, cycle threshold (Ct) 25-27을 보이는 검체를 결핵 강양성, Ct 30-32를 보이는 검체 를 결핵 약양성, NTM Ct 25-27을 보이는 검체를 NTM 양성 으로 선정하였다. 선정된 검체는 $1.8 \mathrm{~mL}$ cryovial tube에 1.5 $\mathrm{mL}$ 씩 소분하였으며, 전 과정 일정분리원칙을 준수하여 검체 뒤바뀜, 검체 간 오염, 기타 사무적 오류를 보일 수 있는 가능 성을 줄이고자 하였다. 이후 제작된 검체를 무작위 $8 \mathrm{sets}$ 를 선 택하여 실시간중합효소연쇄반응검사를 시행하였으며, 실시간 중합효소연쇄반응검사 검증은 식약처를 통해 체외진단기기 판매허가를 취득한 국내에서 많이 사용하고 있는 결핵균핵산 증폭검사 진단키트를 종류별로 이용하여 제작된 검체의 확인 검사, 약양성 검체의 $\mathrm{Ct}$ 값 비교 등 제조물질의 사전, 사후 검 증을 수행하였다.

\section{5. 항산균 신속약제 감수성검사의 정도관리}

항결핵제 감수성검사 정도관리를 위해 선별된 panel strain 중에서 4개의 균주를 선정하였으며, 선정된 균주는 INH와 $\mathrm{RIF}$ 내성과 연관 있는 유전자 $(r p o B, k a t G, \mathrm{inh} A, a p h C)$ 의 변이를 분석하였다. 결과는 감수성 또는 내성으로 입력하도록 하였고, 검출된 유전자형은 국제 명명분류법(nomenclature) 통일이 되지 않음으로 비교자료로만 입력하도록 하였다.

$\mathrm{WHO}$ 감수성검사 정도관리 균주 중에서 $\mathrm{INH}$ 와 $\mathrm{RIF}$ 감수 성 결과와 유전자변이 정보가 있는 2 종의 균주를 정도관리 균 주로 선정하였다.

검체 제작과정으로는 선정된 $\mathrm{WHO}$ 정도관리 균주 2 종을 계대 배양하여 위와 마찬가지로 비동화 제작하였다. 이후 무 작위 $8 \mathrm{sets}$ 를 선택하여 LPA와 핵산 염기서열분석(DNA sequencing) 및 Xpert를 통해 검증하였으며, LPA 검증의 경 우 식약처를 통해 체외진단기기 판매허가를 취득한 국내에서 많이 사용하고 있는 신속약제 감수성검사 진단키트를 종류별 로 이용하여 제작된 검체에 대하여 사전비교 검증을 시행하였 다.

\section{결과}

\section{1. 항산균 도말검경의 정도관리}

2017년 항산균검사 도말검경 신빙도조사 참여기관 수는 1 차 257기관, 2 차 262 기관, 3 차 272 기관이었으며, 2018년 참 여기관 수는 1 차 274 기관, 2 차 269 기관, 3 차 274 기관으로 2017년 대비 26개 참여기관이 증가하였다. 일부 의료기관의 Clinical and Laboratory Standards Institute 기준에 따른 보고와 신빙도조사사업 데이터베이스의 $\mathrm{WHO}$ 판정기준 적용 지연 등의 문제로 주요 오류(major error)를 제외한 정량오류 의 경우 판정기준 \pm 2 내외의 답안의 경우 인정하였다. 각 가 이드라인의 판정기준 차이에 따른 정량적 오류를 제외한 주 요 오류의 경우 2017년 총 196건이었으나, 2018년 총 9건으 로 감소하였다. 2017년 2차 정도관리 음성 검체로 제공된 MT17-11, MT-17-15의 경우 scanty, 1+로 판정된 사례가 각각 $48.26 \%, 62.3 \%$ 로 나타났다. 2018 년 참여기관의 회신결과 판 정기준 변경에 따른 정량오류를 제외한 건에 있어서 양 - 음성 결과 반전에 대한 이의제기가 2 건 있었으나, 검체 회수 후 검 증결과 라벨링 재부착 흔적이 발견된바 차후 모든 외부정도관 리 검체에 훼손방지 스티커를 일괄 부착하여 제공할 예정이다. 정도관리결과는 Table 4와 Table 5에 요약하였다. 
Journal of LABORATORY MEDICINE and QUALITY ASSURANCE

Soyoun Shin et al • Report on Clinical Mycobacteriology EQA Program
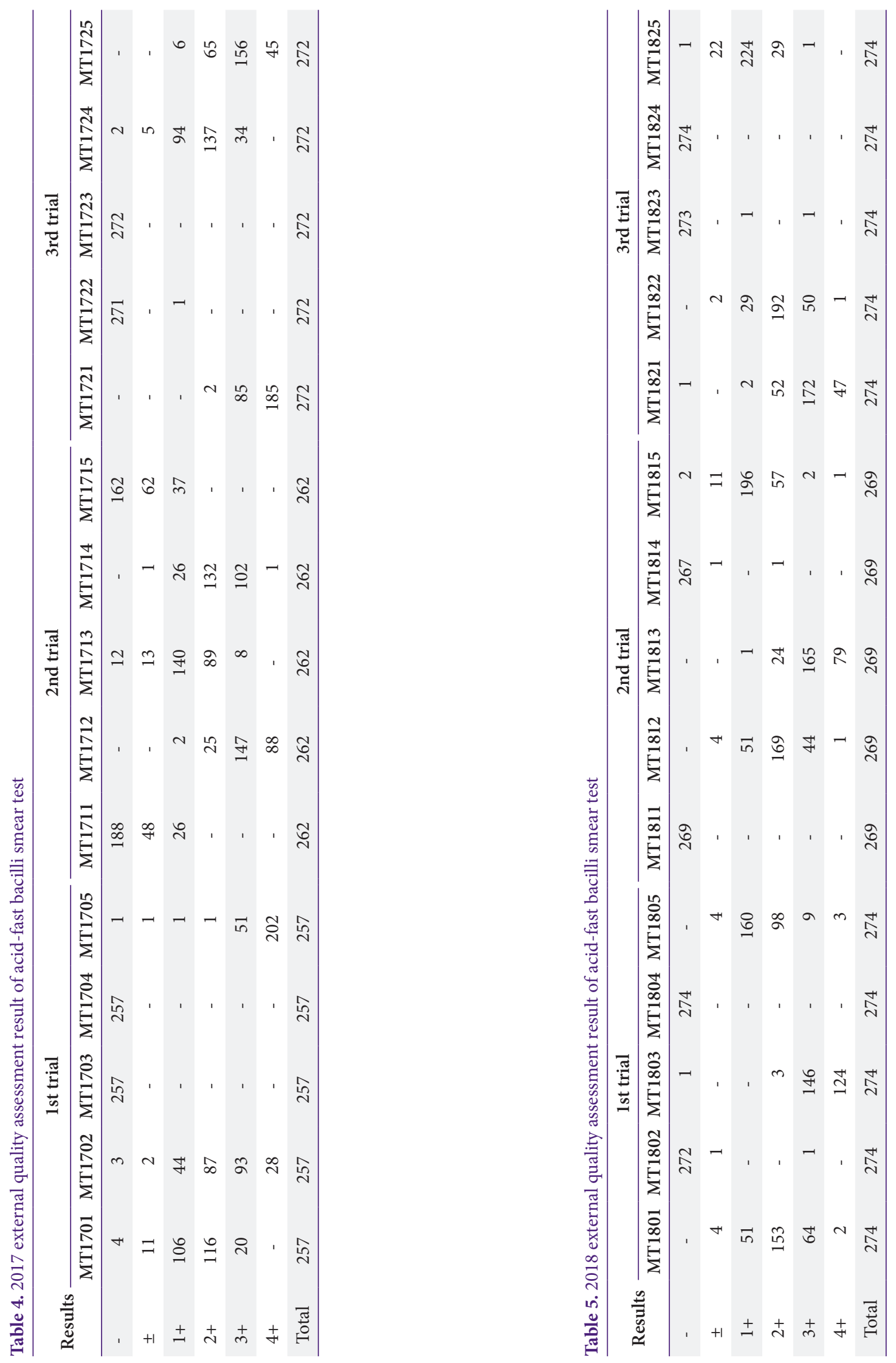


\section{2. 항산균 배양검사의 정도관리}

2017년 항산균 배양검사의 신빙도조사 참여기관 수는 1차 109 기관, 2 차 112 기관, 3 차 113 기관이었으며, 2018년에는 1 차 96 기관, 2 차 110 기관, 3 차 112 기관이 참여하였다. 2017년 항산균 배양검사 정도관리결과는 Table 6, 2018년 항산균 배 양검사 정도관리 결과는 Table 7에 요약하였다.

\section{3. 항산균 균종동정검사의 정도관리}

2017년 항산균 배양검사의 신빙도조사 참여기관 수는 1차 58 기관, 2 차 58 기관, 3 차 57 기관이었으며, 2018년에는 1차 64 기관, 2 차 68 기관, 3 차 69 기관이었다. 2017년 항산균 균종동 정검사 정도관리결과는 Table 8에 요약하였으며, 2018년 항산 균 균종동정검사 정도관리결과는 Table 9에 요약하였다.

대한임상검사정도관리 신빙도조사프로그램 자료에 따르면, 지난 2년간 항산균 균종동정검사 신빙도조사에서 가장 많은 질의를 받은 검체는 MT-18-29로 M. chelonae (NTM)를 포 함하고 있는 검체이다. 12 개 기관에서 M. chelonae로 정확한 결과를 보고하였고, 24 개 기관에서 NTM으로 보고하였으나, 33개 기관이 no growth로 보고하였다. M. chelonae (NTM) 는 신속발육 비결핵항산균의 일종으로 피부감염을 잘 일으키 는 균종이며, M. marium, M. ulcerans, M. haemophilium 과 함께 $25^{\circ} \mathrm{C}-33^{\circ} \mathrm{C}$ 에서 잘 증식하고 $37^{\circ} \mathrm{C}$ 에서 잘 증식하지 않 는 특성이 있어 이러한 균종에 의한 감염이 의심되는 경우 저 온배양을 시행하여야 한다. 매년 증가하고 있는 다양한 비결핵 항산균 감염의 적절한 배양 및 균종동정검사가 시행될 수 있도 록 이에 대한 고려가 필요할 것으로 생각된다.

\section{4. 항결핵제 감수성검사의 정도관리}

항결핵제 감수성검사의 정도관리는 2017년, 2018년 각 3회 시행되었으며, 각 회차 9 개의 참여기관에 5 개의 $\mathrm{WHO}$ 표준 균주가 발송되었다. 결과를 회신한 기관은 2017년 1차 4개 기 관, 2 차 3 개 기관, 3 차 모두 6 개 기관이었고, 2018년 1차 5 개 기관, 2 차 5 개 기관, 3 차 5 개 기관이었으며, 검사법 이용현황 은 Table 10에 기술하였다. 검체 발송 전 각 약제별 MIC와 내 성유전자 변이가 분석되었으며, 검체는 고위험 감염체로 분류 되어 우편발송이 아닌 기관 직접 배송을 하였다. 2017년 항결 핵제 감수성검사 정도관리결과는 Table 11에 요약하였으며, 2018년 항결핵제 감수성검사 정도관리 결과는 Table 12에 요 약하였다.

대한임상검사정도관리협회 신빙도조사 항결핵제 감수성검 사 외부정도관리는 참여기관의 수가 적고 참여기관별 검사법 이 서로 상이하여 특정 약제에 있어 결과 일치율이 높지 않았

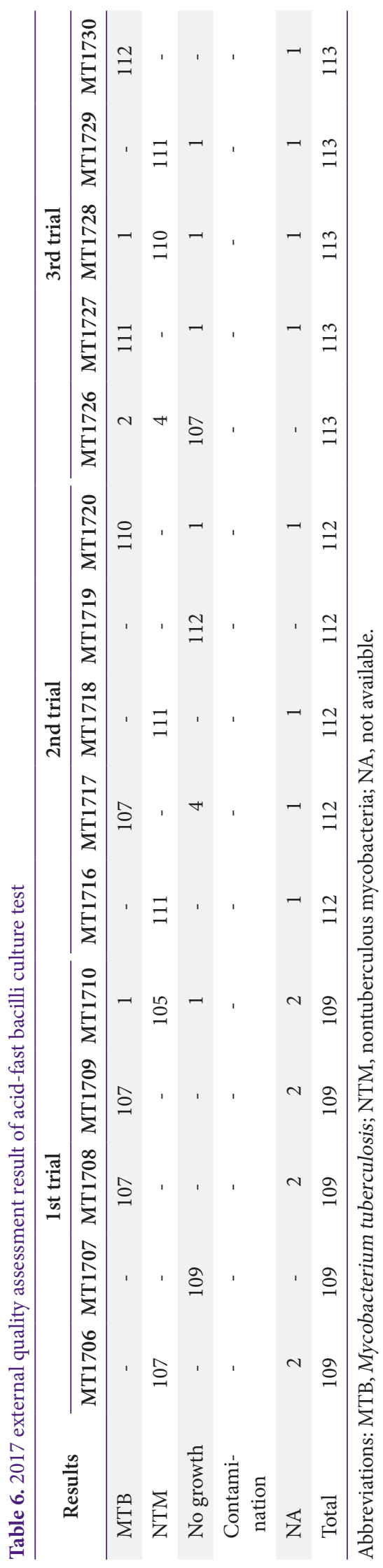


Journal of LABORATORY MEDICINE and QUALITY ASSURANCE

Soyoun Shin et al $\bullet$ Report on Clinical Mycobacteriology EQA Program
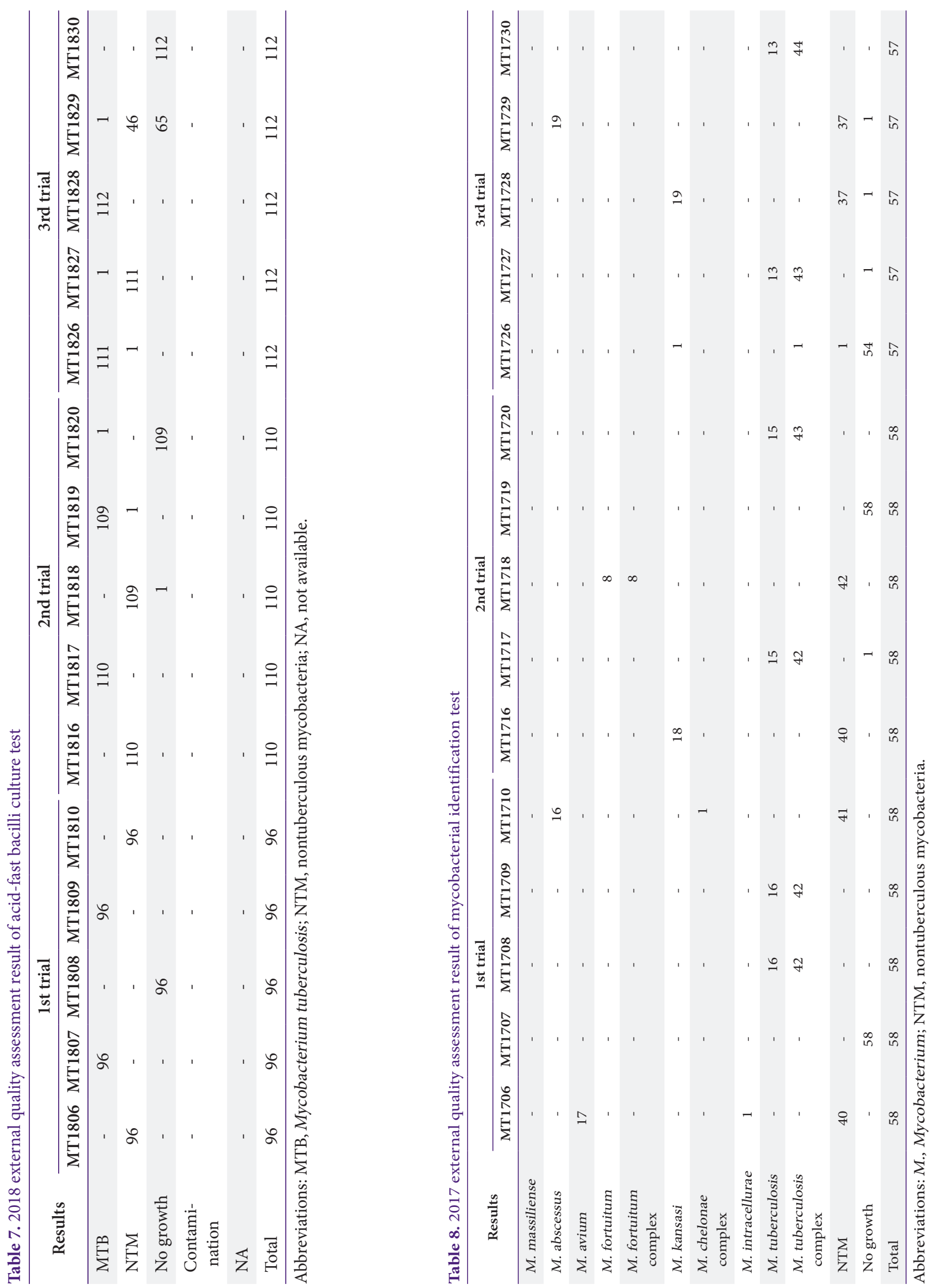


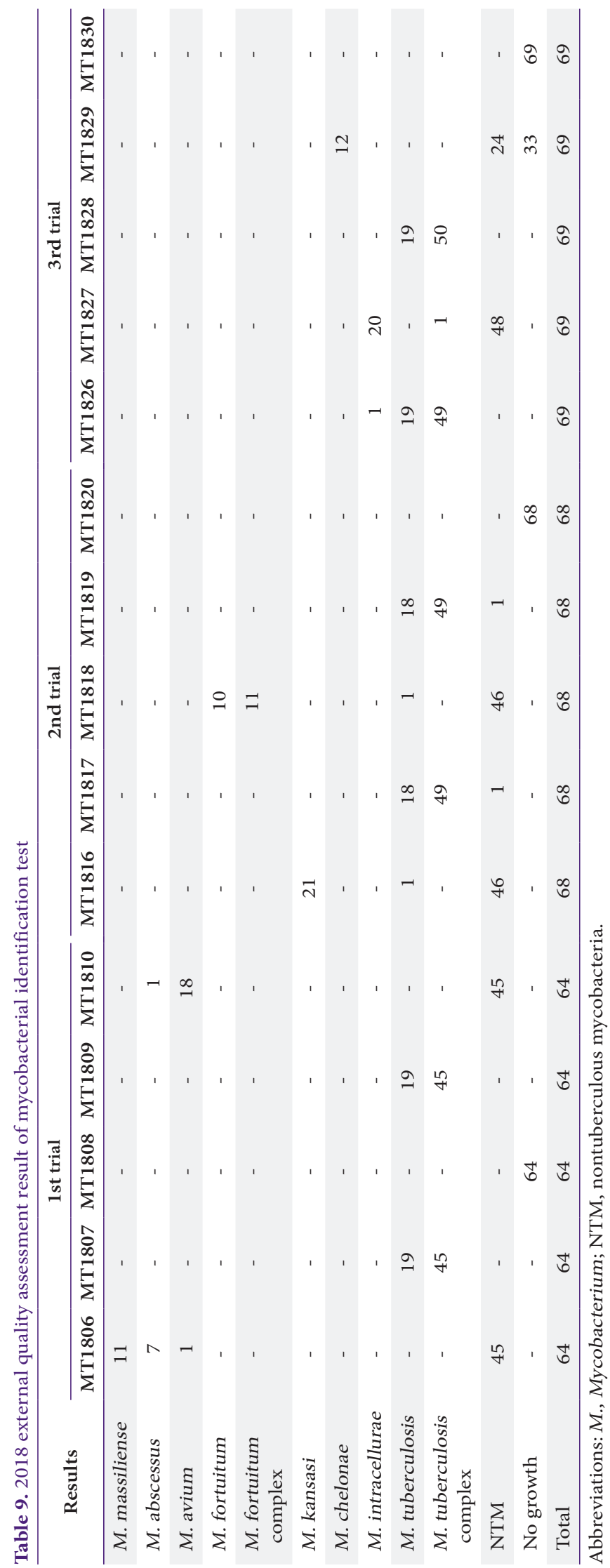

다. 또한 $\mathrm{INH}, \mathrm{RIF}$ 과 같은 주요 1 차 약제에서 정답 불일치를 보이는 기관들이 있었으며, 2018년 4월 WHO 가이드라인상 에 항결핵제의 임계 농도값(critical concentration)의 개정이 있었으므로 각 참여기관들의 판정기준 재검토와 더불어 가능 할 시 신속약제 감수성검사 재확인 절차가 필요할 것으로 고려 된다[7].

\section{1) 결핵균 분자동정검사의 정도관리}

2017년 결핵균 분자동정검사의 1차 신빙도조사에서는 양 - 음성 2 개의 검체가 제공되었으나, 2 차 신빙도조사에서 시 범사업으로 약양성 검체 1 개를 추가 제공하였으며, 2018년 결 핵균 분자동정검사에서는 약양성 검체를 정식프로그램에 포 함하여 총 3 개의 검체가 제공되었다. 가장 많이 사용된 실시 간중합효소연쇄반응검사 키트는 Advansure TB/NTM realtime PCR (LG Chemical, Seoul, Korea)이었으며, 2017년 3 개 기관, 2018년 5개 기관에서 GeneXpert MTB/RIF assay (Cepheid)를 이용하여 신빙도조사에 참여하였다. Xpert는 장 비지침상에 전처리를 하지 않은 순수객담을 검체로 권고하고 있으며, 대한임상검사정도관리협회의 신빙도조사에 제공되는 외부정도관리 검체는 액상의 균주 균질액이므로 추후 별도의 정도관리물질 제작 및 프로그램 운영 구분이 필요할 것으로 생 각된다. 2017년 2차 정도관리에서 시범사업으로 시작한 약양 성 검체의 일치율이 시행 초기 $82.5 \%$ 를 보였으나, 2018년 3차 정도관리결과 기준 $99.2 \%$ 까지 향상되었다. 결과는 Table 13 과 Table 14에 요약하였다.

\section{2) 결핵균 신속약제 감수성검사의 정도관리}

2017년 결핵균 신속약제 감수성검사 외부정도관리에 참여 한 기관 수는 1 차 53 개 기관, 2 차 55 개 기관, 3 차 63 개 기관이 었으며, 2017년에는 1 차 69 개 기관, 2 차 69 개 기관, 3 차 70 개 기관으로 회차별 참여기관 수의 점진적인 증가를 보였다. 검체 는 각 회차별 INH, RIF 내성 혹은 감수성 조합으로 2 개의 검 체가 제공되었다. 제공된 검체의 내성 여부와 유전자변이 부위 는 Table 15에 요약하였으며, 결과는 Tables 16-19에 요약하 였다. 2018년 기준 참여기관 수의 $41 \%$ 에 해당하는 기관들이 $\mathrm{RIF}$ 내성검사 외부정도관리에 Xpert를 사용하는 것으로 나타 났으나, Xpert는 장비지침상에 전처리를 하지 않은 순수객담 을 검체로 권고하고 있으며, 대한임상검사정도관리협회의 신 빙도조사에 제공되는 외부정도관리 검체는 액상의 균주 균질 액이므로 추후 별도의 정도관리물질 제작 및 프로그램 운영 구 분이 필요할 것으로 생각된다. 그 외 GenoType MTBDRplus (Hain Lifescience, Nehren, Germany), AdvanSure MDR- 
Journal of LABORATORY MEDICINE and QUALITY ASSURANCE

Soyoun Shin et al • Report on Clinical Mycobacteriology EQA Program

Table 10. Antituberculous DST methods used

\begin{tabular}{|c|c|c|c|c|c|c|}
\hline Drugs & \multicolumn{3}{|c|}{2017} & \multicolumn{3}{|c|}{2018} \\
\hline Capreomycin & 1 & 2 & - & 1 & 2 & - \\
\hline Cycloserine & - & 2 & - & - & 2 & - \\
\hline Isoniazid & 1 & 2 & 2 & 1 & 2 & 2 \\
\hline Kanamycin & 1 & 2 & - & 1 & 2 & - \\
\hline Levofloxacin & 1 & 2 & - & 1 & 2 & - \\
\hline Moxifloxacin & 1 & 2 & - & 1 & 2 & - \\
\hline Ofloxacin & 1 & 2 & - & 1 & 2 & - \\
\hline Pyrazinamide & 1 & 2 & - & 1 & 2 & - \\
\hline Rifabutin & 1 & 2 & - & 1 & 2 & - \\
\hline Rifampin & 1 & 2 & 2 & 1 & 2 & 2 \\
\hline Streptomycin & 1 & 2 & - & 1 & 2 & - \\
\hline
\end{tabular}

Abbreviations: DST, drug susceptibility testing; MGIT, mycobacterial growth indicator tube; PAS, para-aminosalicylic acid.

TB GenoBlot Assay (LG Chemical), MolecuTech REBA MTB-MDR (YD Diagnostics, Yongin, Korea) 등 LPA 기반 의 검사키트를 사용하는 참여기관 수가 2017년 INH 내성검사 의 경우 전체 참여기관의 $71.4 \%, \mathrm{RIF}$ 내성검사의 경우 $31.7 \%$ 였으며, 2018년은 INH 내성검사의 경우 전체 참여기관의 $77.8 \%, \mathrm{RIF}$ 내성검사의 경우 $30.0 \%$ 로 나타났다. 실시간중합 효소연쇄반응검사 키트상에서 약제내성 여부를 판정할 수 있 는 Anyplex MDR-TB detection (Seegene, Seoul, Korea)를 이용하는 참여기관 수는 2017년 $\mathrm{INH}$ 내성검사의 경우 전체 참여기관의 $14.3 \%$, RIF 내성검사의 경우 $6.3 \%$ 였으며, 2018 년은 $\mathrm{INH}$ 내성검사의 경우 전체 참여기관의 $11.1 \%, \mathrm{RIF}$ 내 성검사의 경우 $4.3 \%$ 였다.

\section{고찰}

2018년 건강보험심사평가원의 자료에 따르면(Figs. 1-7), 결핵진단검사의 전년 대비 검사건수는 다소 감소하였으 나 비용은 증가하였으며, 전체 결핵진단검사의 검사건수는 $3,550,880$ 건, 비용은 총 $72,443,134,000$ 원이었다. 검사행위별 통계는 Table 20에 요약하였으며, 2018년도 자료는 현재 미 취합상태로 통계에서 제외하였다. 2012년 이래로 검사건수가
큰 폭으로 증가한 검사는 Xpert $\mathrm{MTB} / \mathrm{RIF}$ 와 결핵반응검사 (interferon gamma releasing assay, IGRA)였고 $(P=0.009$, $P=0.001$ ), 검사종목 전반으로는 감소세를 보였으며, 특히 직 접형광도말, nested $\mathrm{TB} \mathrm{PCR}$ 에서 큰 폭의 감소세를 보였다 $(P=0.046)$. 도말검사의 전체 이용건수는 집균형광도말을 제 외한 전 항목에서 6 년간 꾸준한 감소세를 보였으며, 이는 각 의료기관들이 검출률이 높은 집균형광도말로 검사법을 대체 함에 따른 것으로 생각된다. 고체 및 액체배양검사에서는 액 체배양이 꾸준한 증가세를 보였으며, 이는 액체배양 보험수가 지정에 따라 고체 및 액체배양의 병행검사 증가에 기인한 것 으로 생각되며 지속적인 증가가 예상된다. 도말검사건수와 고 체배양건수는 이전 통계와 유사한 3-40만 건의 격차를 보였으 나, 핵산증폭검사에서는 $\mathrm{PCR}$ 교잡법에 해당하는 항목만 증가 하고 TB-PCR, nested TB-PCR은 모두 감소하였다. Xpert $\mathrm{MTB} / \mathrm{RIF}$ 는 비급여검사 시행이 많으므로 실제 검사건수를 가늠하기 어려우나, 2018년 건강보험심사평가원의 지침 개정 에 의거 LPA 기반 검사와 Xpert의 중복시행이 인정됨에 따라 2019년 전년도 대비 시행건수의 증가가 예상된다. 잠복결핵검 사의 종류는 TST와 IGRA 두 가지인데, TST는 감소하는 반면 IGRA는 큰 폭으로 증가하였다. 2017년 결핵안심국가 실행계 획에 따른 의료기관 종사자 등에 대한 대규모 잠복결핵검진사 
Journal of LABORATORY MEDICINE and QUALITY ASSURANCE

Soyoun Shin et al • Report on Clinical Mycobacteriology EQA Program

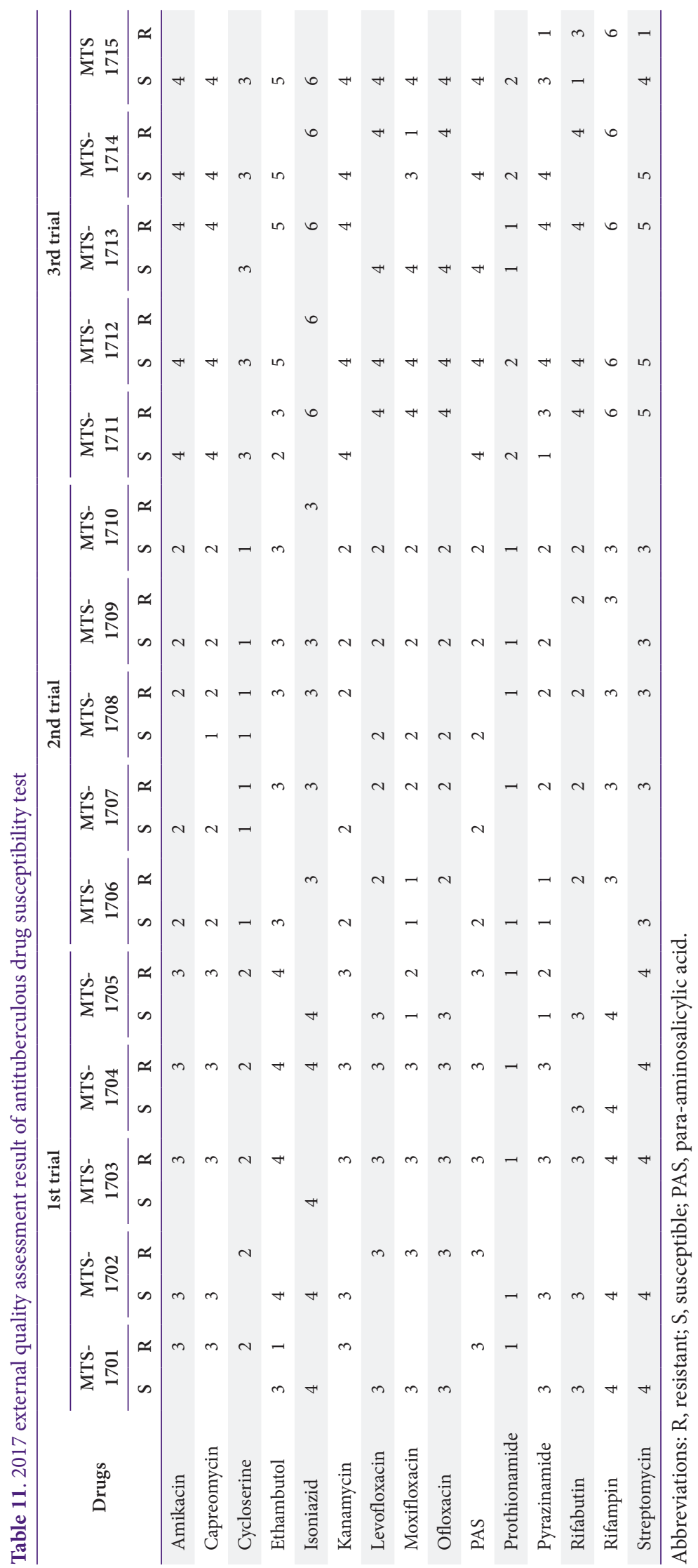




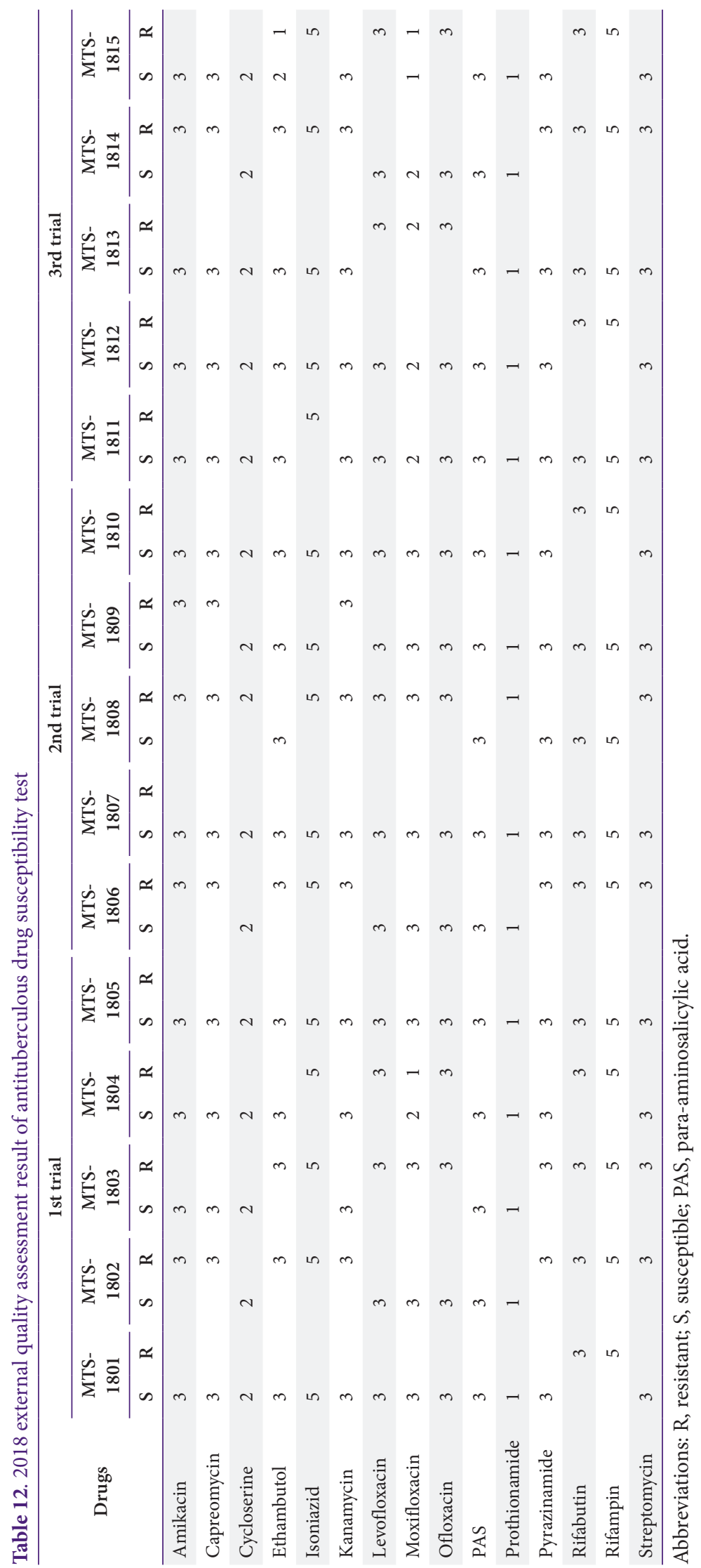


Journal of LABORATORY MEDICINE and QUALITY ASSURANCE

Soyoun Shin et al $\bullet$ Report on Clinical Mycobacteriology EQA Program

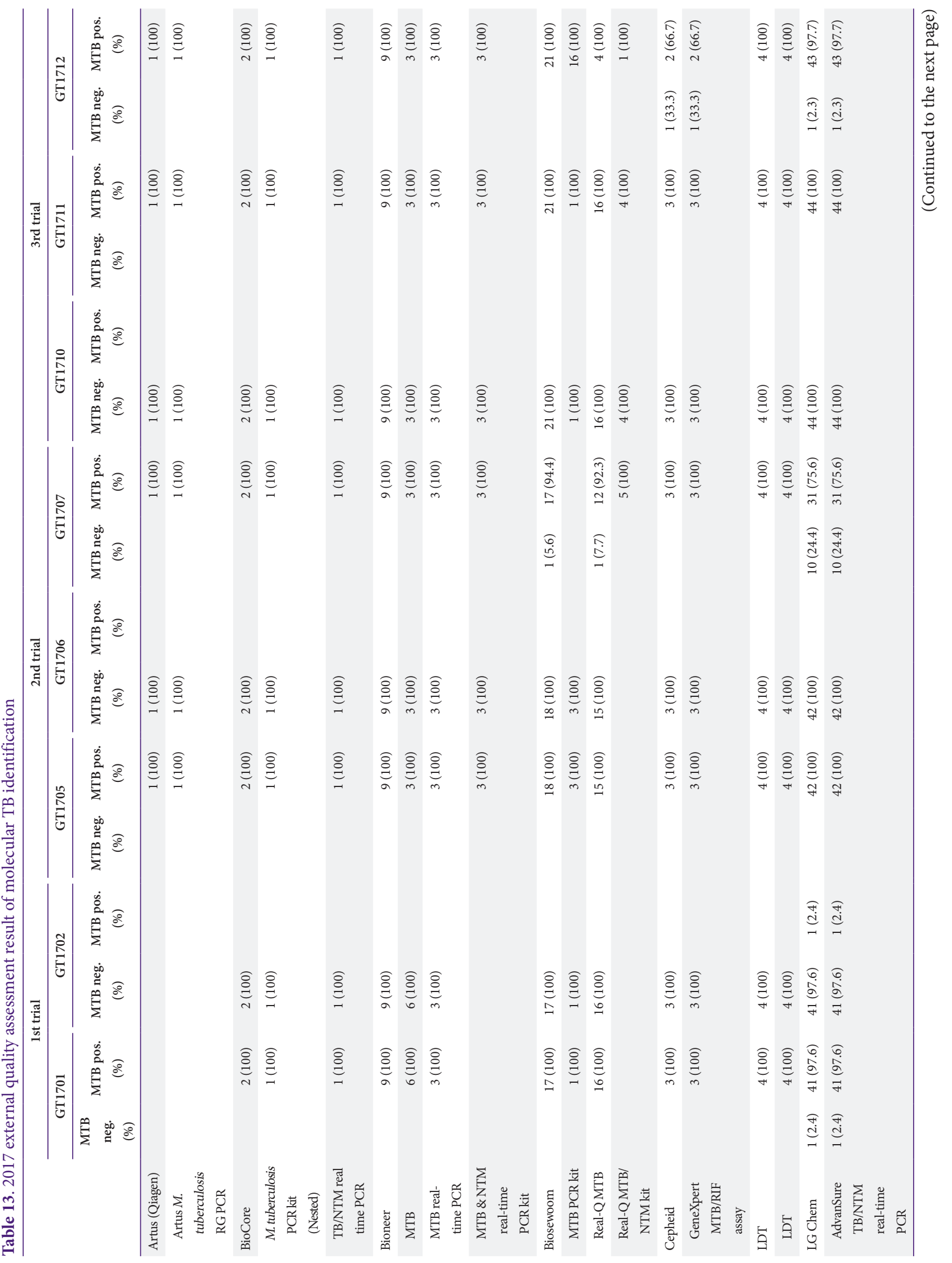




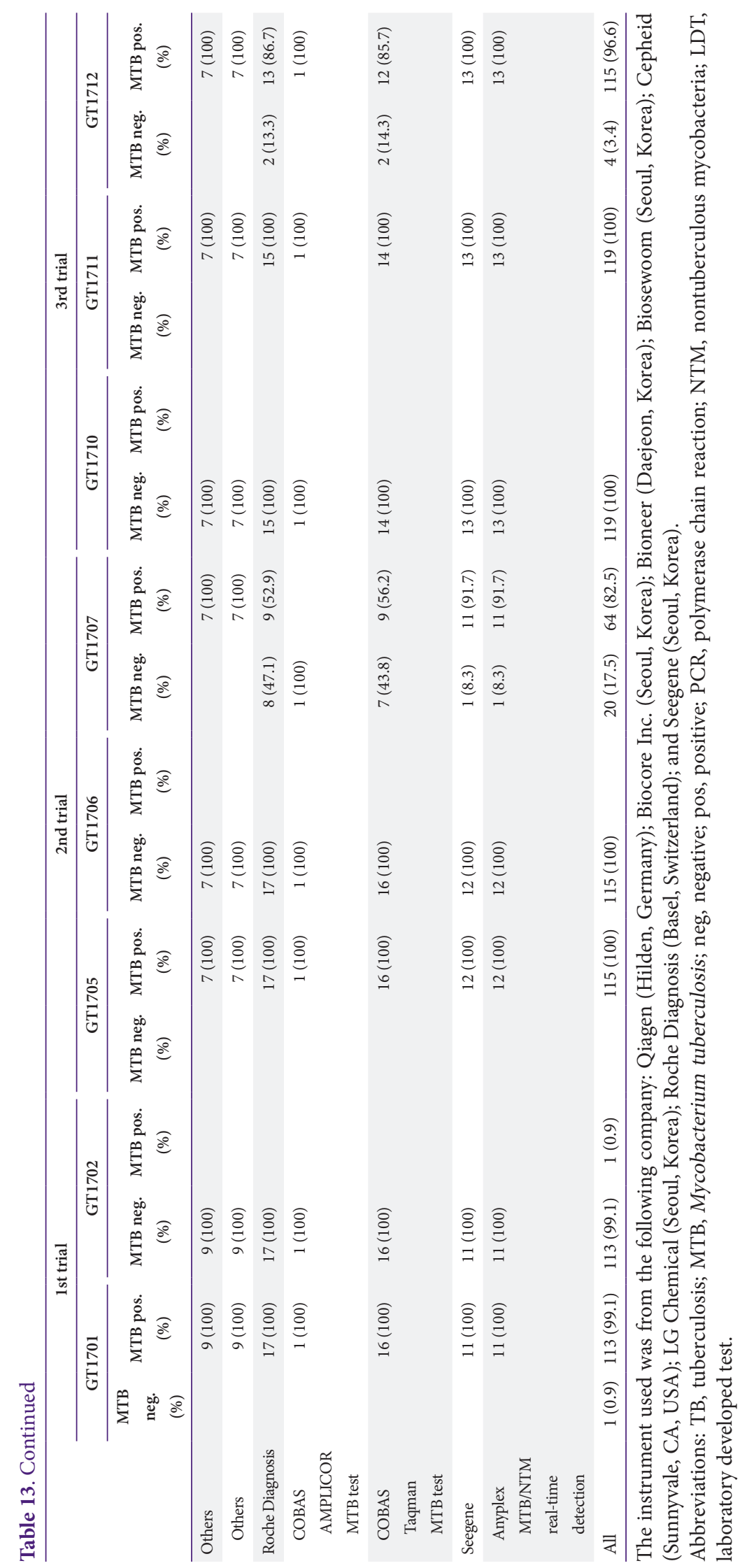




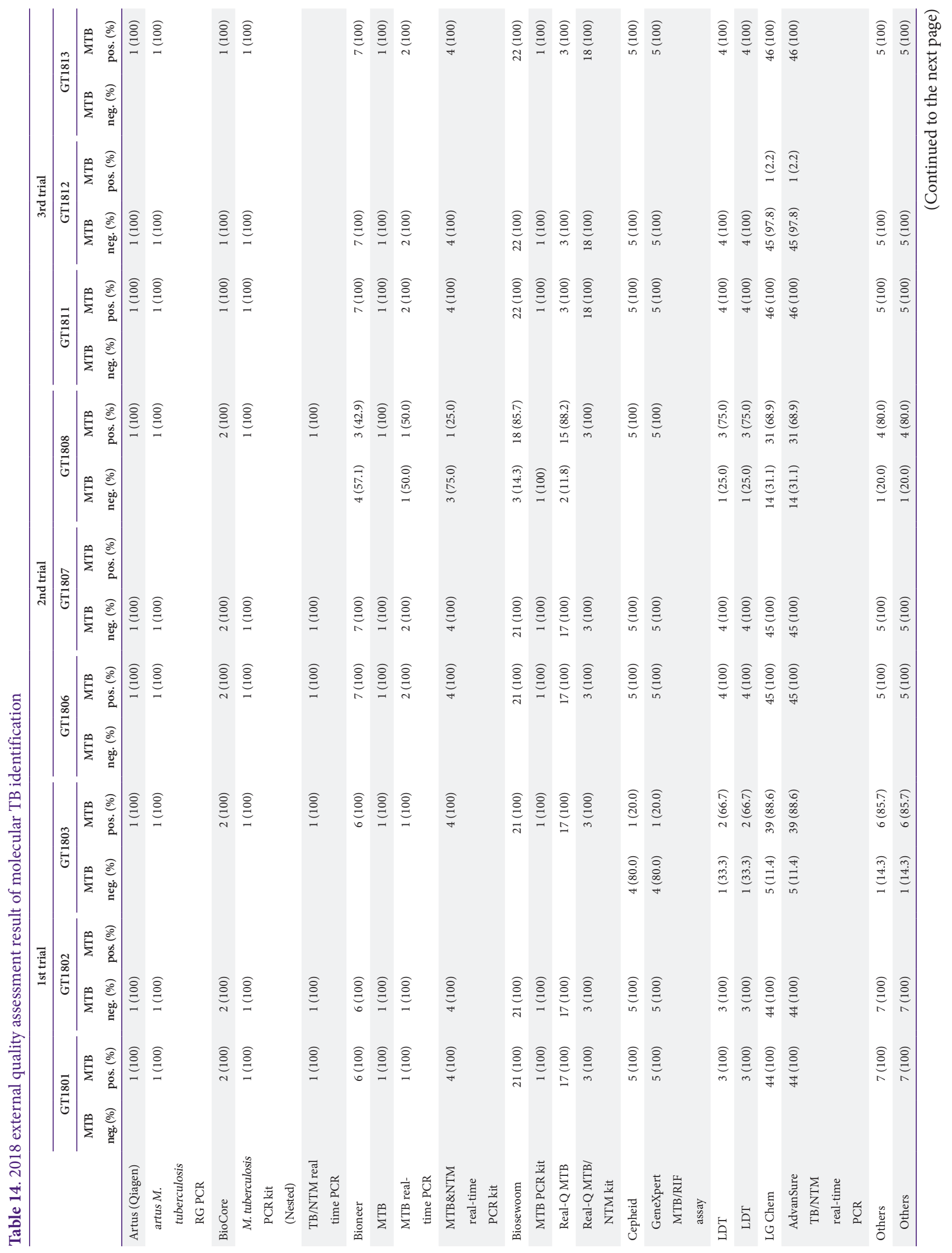



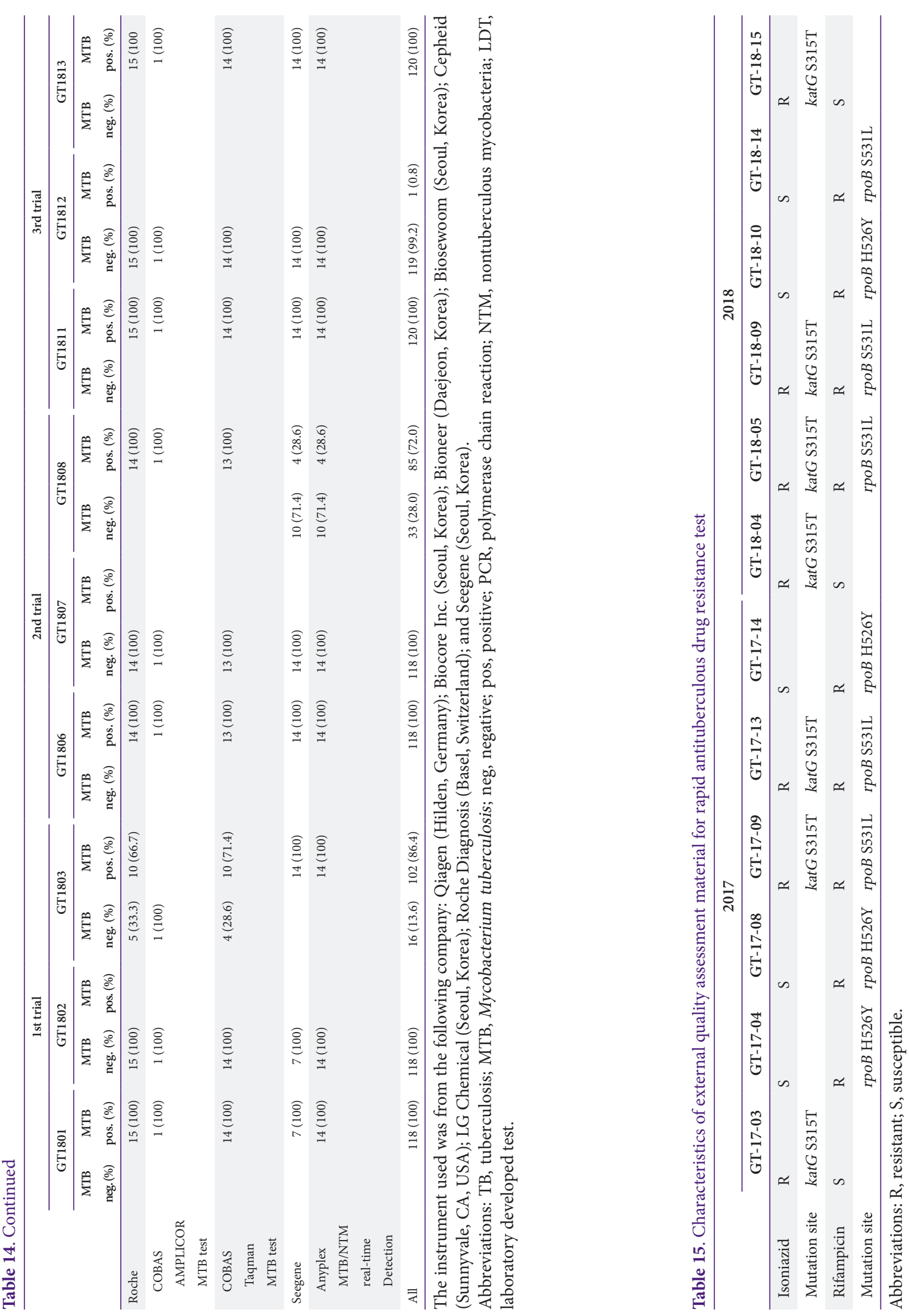


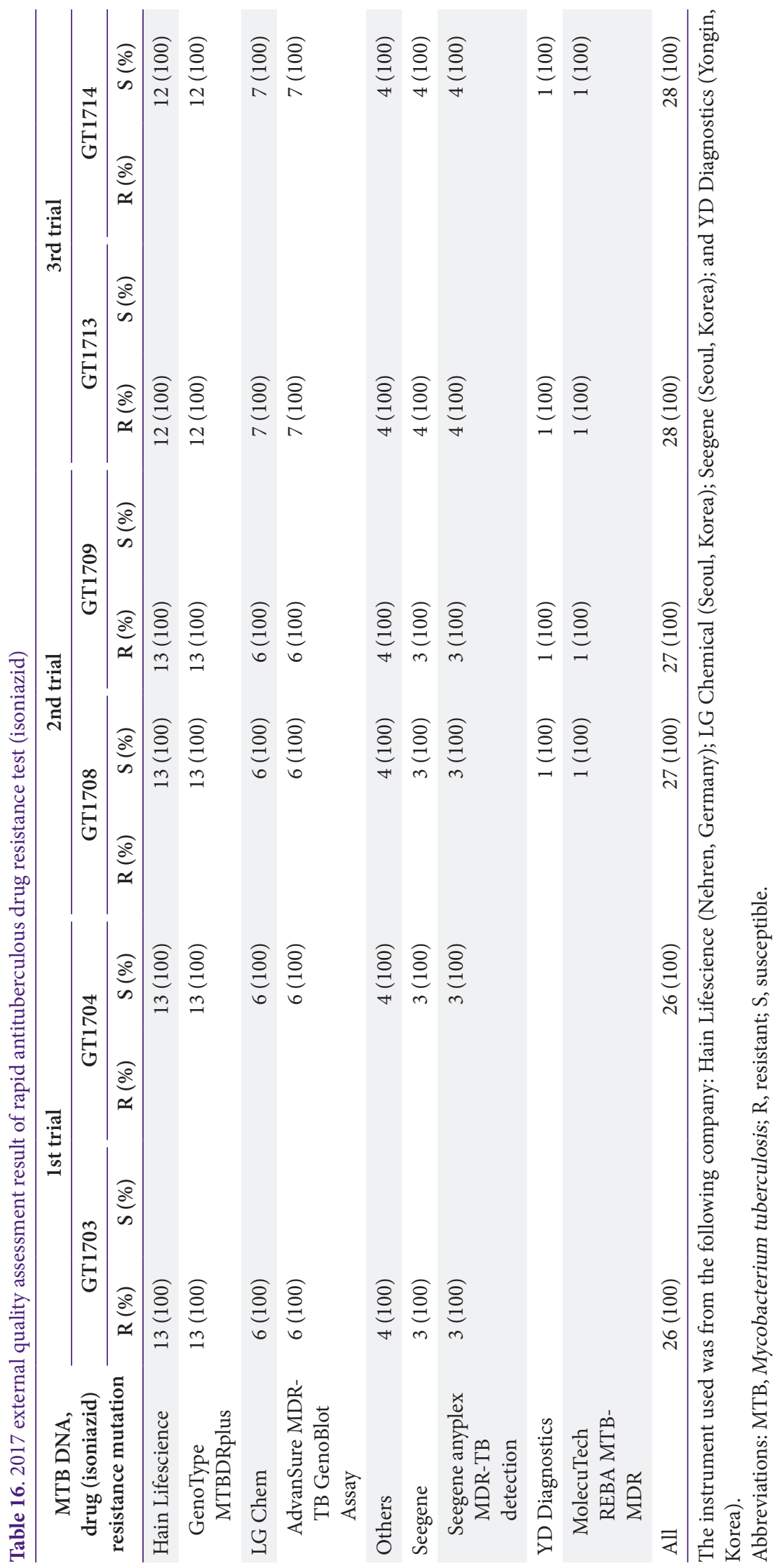




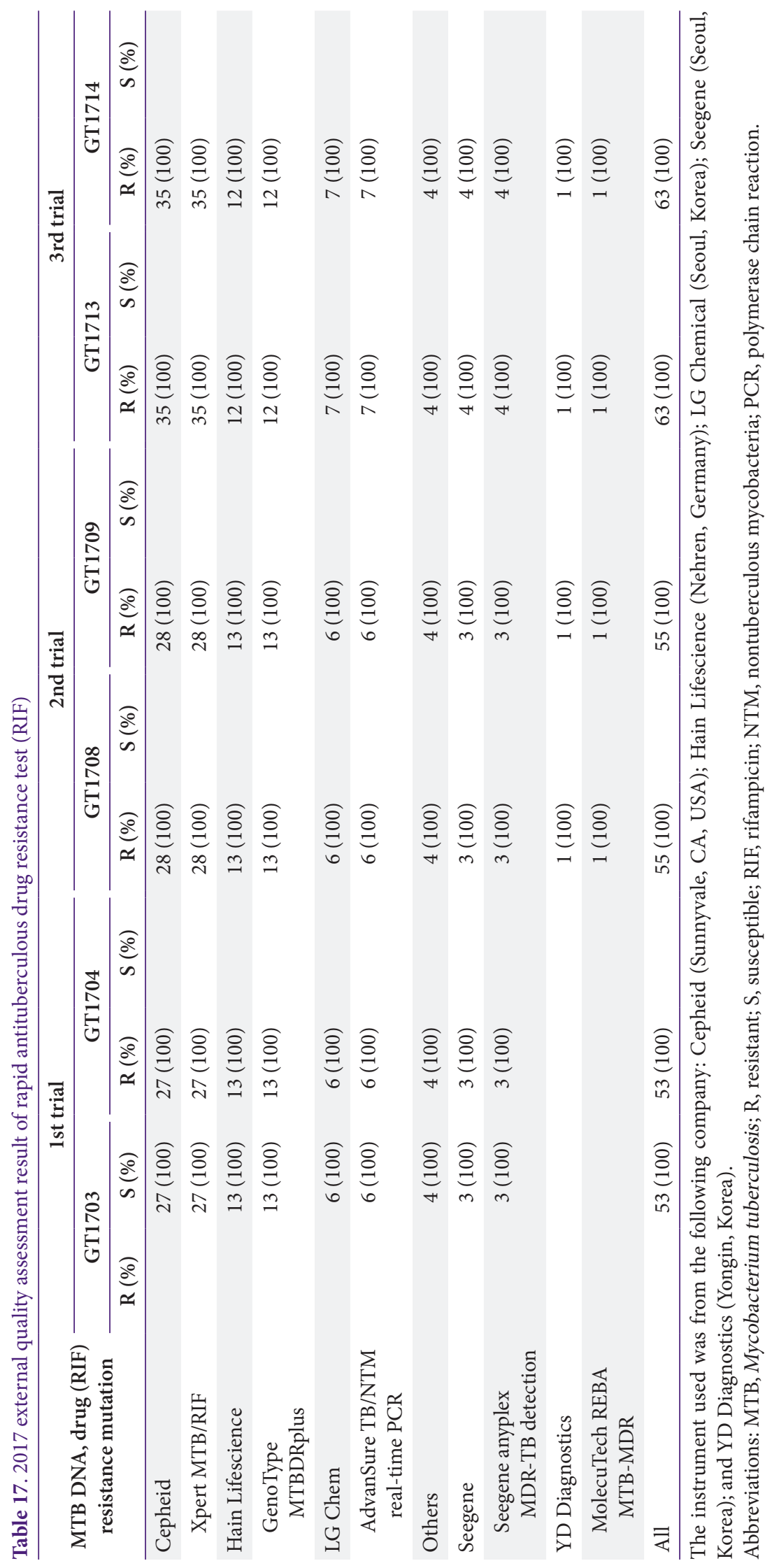


Journal of LABORATORY MEDICINE and QUALITY ASSURANCE

Soyoun Shin et al • Report on Clinical Mycobacteriology EQA Program

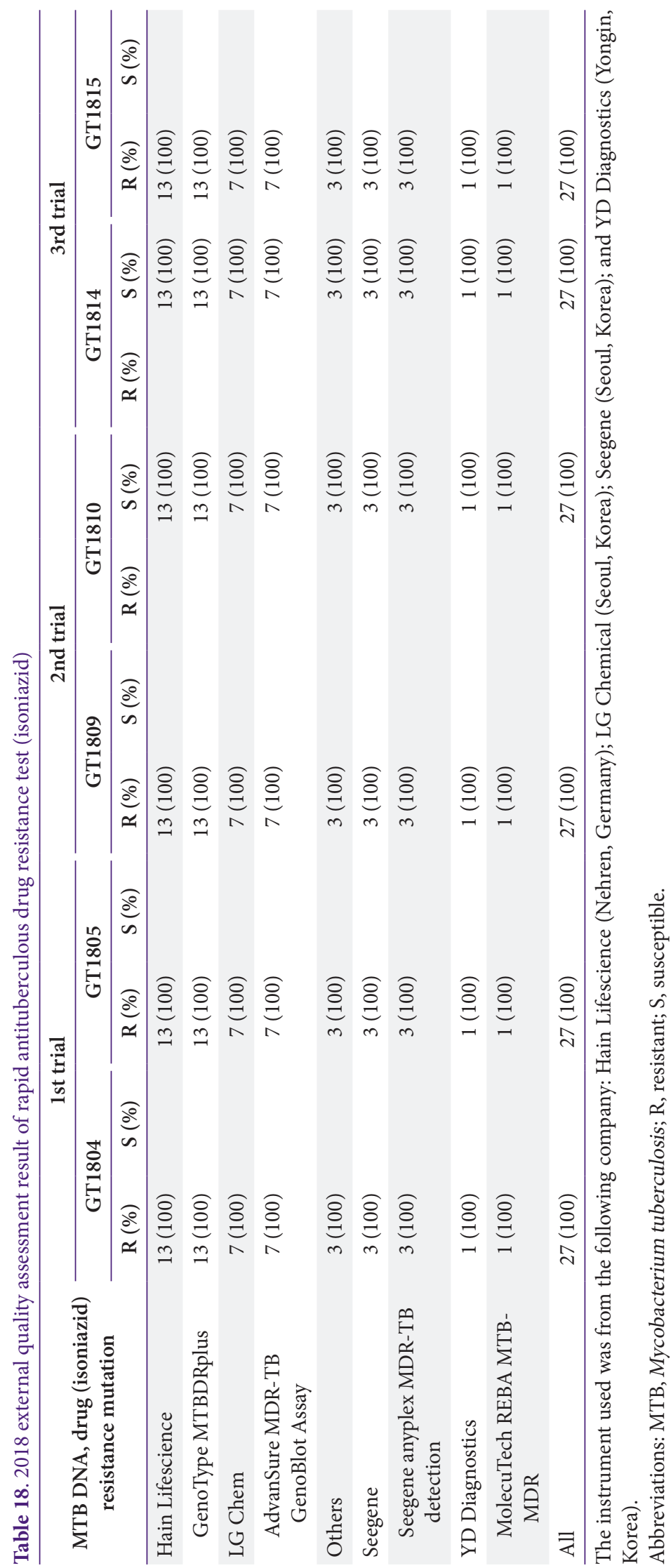




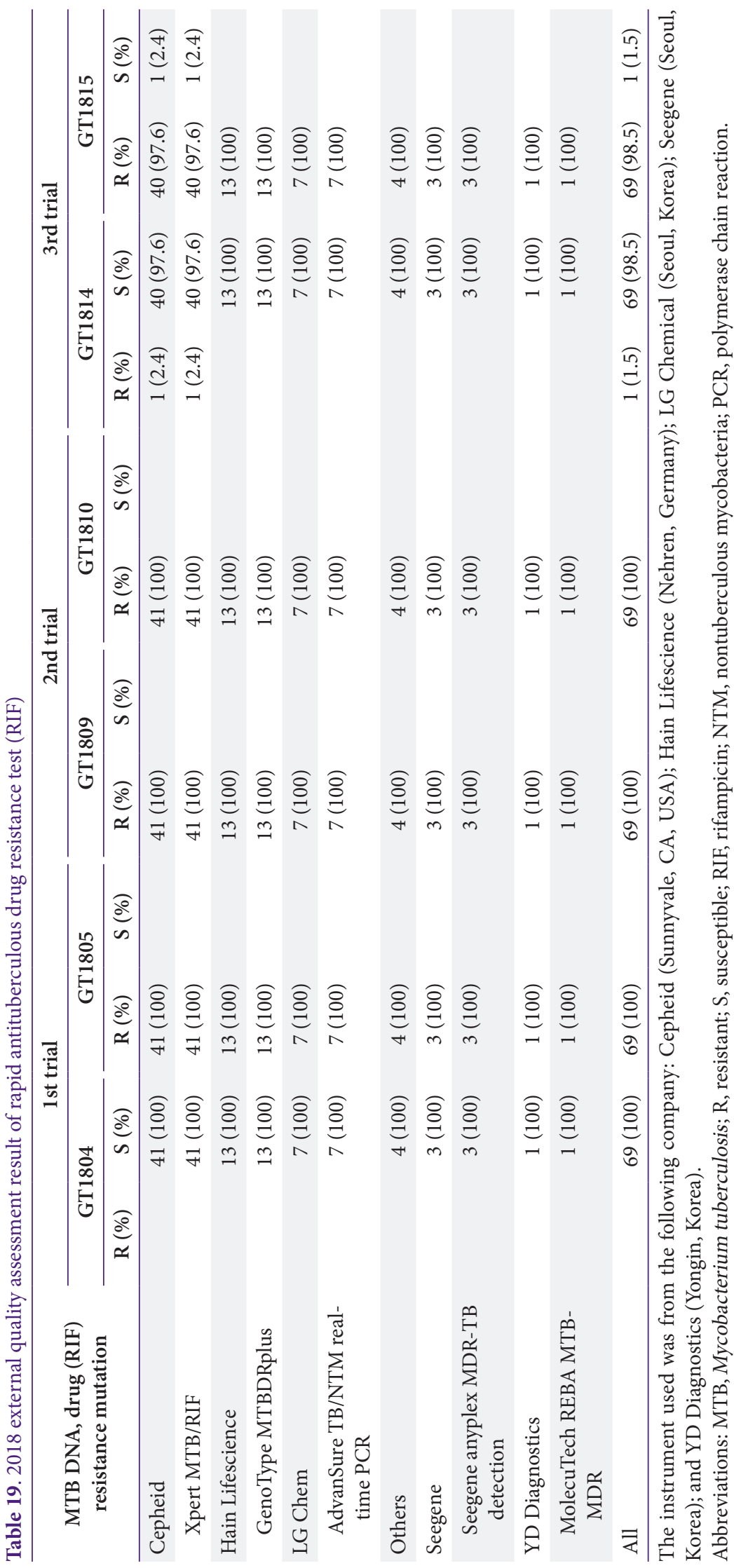




\section{Journal of LABORATORY MEDICINE and QUALITY ASSURANCE}

Soyoun Shin et al $\bullet$ Report on Clinical Mycobacteriology EQA Program

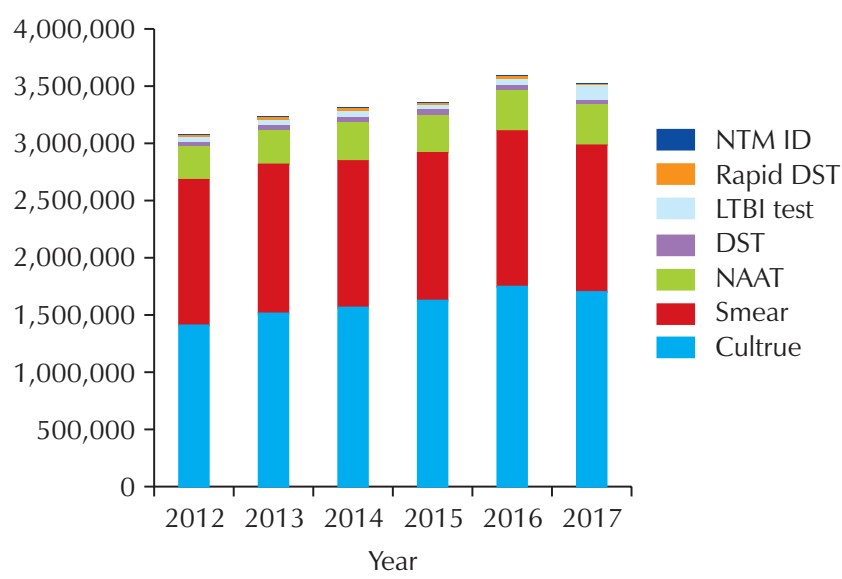

Fig. 1. Domestic tuberculosis diagnostic test scale performed in 2012-2017 ( $P=0.184)$. Abbreviations: NTM ID, nontuberculous mycobacteria identification; DST, drug susceptibility testing; LTBI, latent tuberculosis infection; NAAT, nucleic acid amplification test.

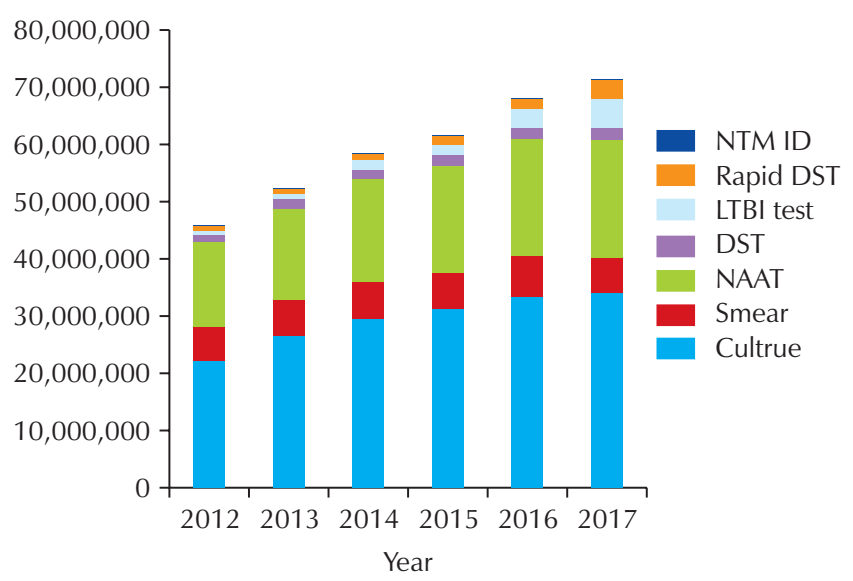

Fig. 2. Test budget used for tuberculosis diagnostics in 2012-2017 ( $P=0.104)$. Abbreviations: NTM ID, nontuberculous mycobacteria identification; DST, drug susceptibility testing; LTBI, latent tuberculosis infection; NAAT, nucleic acid amplification test.

업의 확장에 기인한 것으로 생각된다.

항산균 도말검사 정도관리는 2018 년 $\mathrm{WHO}$ 판독기준의 적 용에 다소 혼선이 있었으나, 대한임상검사정도관리협회와의 긴밀한 협조관계를 통해 2019년 도말검사 정도관리의 신빙도 조사시스템에 $\mathrm{WHO}$ 도말검경 판정기준에 따른 결과입력란이 일괄 적용될 예정이다.

항산균 배양검사 정도관리 참여기관이 작년 98 개 기관에서 금년 110 개 기관으로 증가하였으며, 음성 검체 오염으로 인한

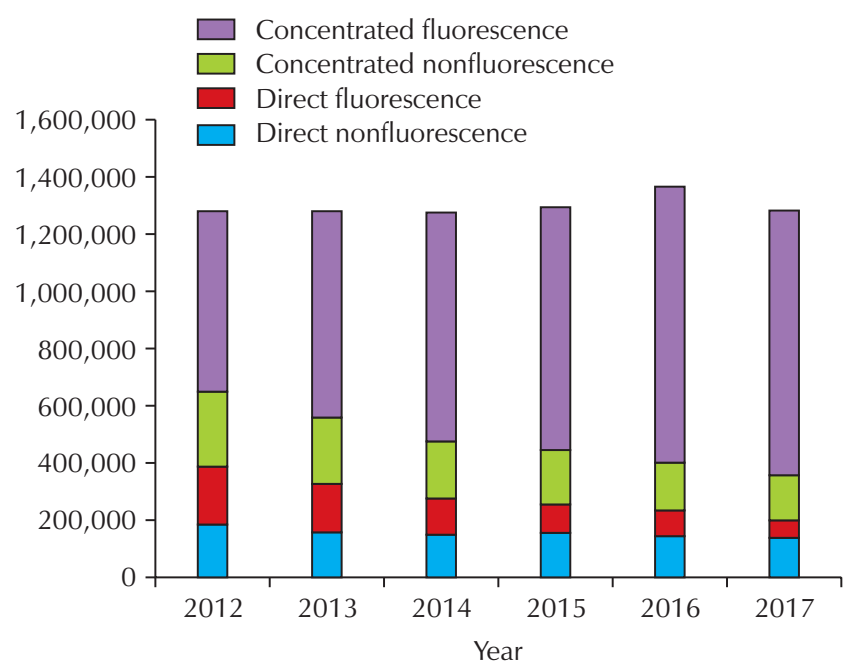

Fig. 3. Domestic acid-fast bacilli test scale performed in 2012-2017 $(P=0.503)$.

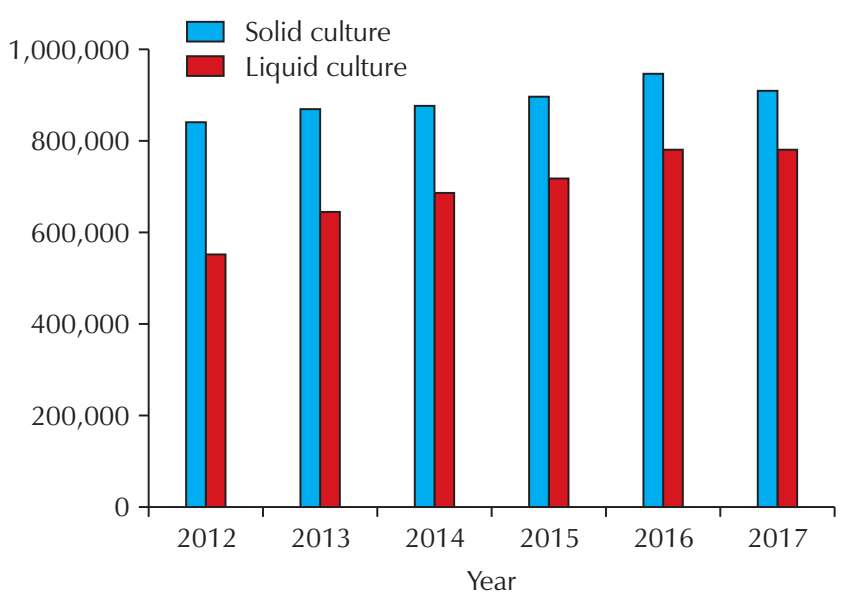

Fig. 4. Domestic tuberculosis culture test scale performed in 2012-2017 $(P=0.202)$.

검체 재요청 사례가 발생하지 않았다.

$\mathrm{WHO}$ 균주를 이용하여 시행한 항결핵제 감수성검사는 분 자 및 세균학적으로 철저하게 규명된 균주를 선정하여 이용하 였으며, INH와 RIF 같은 1 차 약제와 그 외 주요 2차 약제에 대한 결과 일치율이 $98.5 \%$ 이상으로 높았으며, 일치도도 매우 높았다.

항산균 분자동정검사의 외부정도관리에 있어서는 2017년 시범 시행하였던 약양성 검체의 정규프로그램 편입에 따라 2018년 전회 시행하였으며, 물질제작 표준제작지침서의 구축 에 따라 추후 정도관리물질의 안정화가 기대된다. 국내 병 - 의 


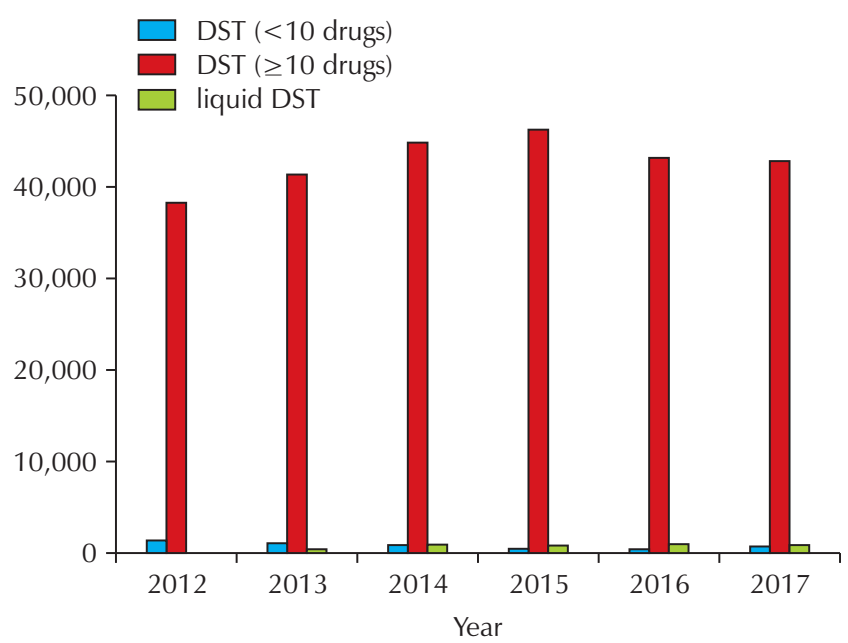

Fig. 5. Domestic test number of tuberculosis DST performed in 2012-2017( $P=0.174)$. Abbreviation: DST, drug susceptibility testing. Abbreviation: DST, drug susceptibility testing.

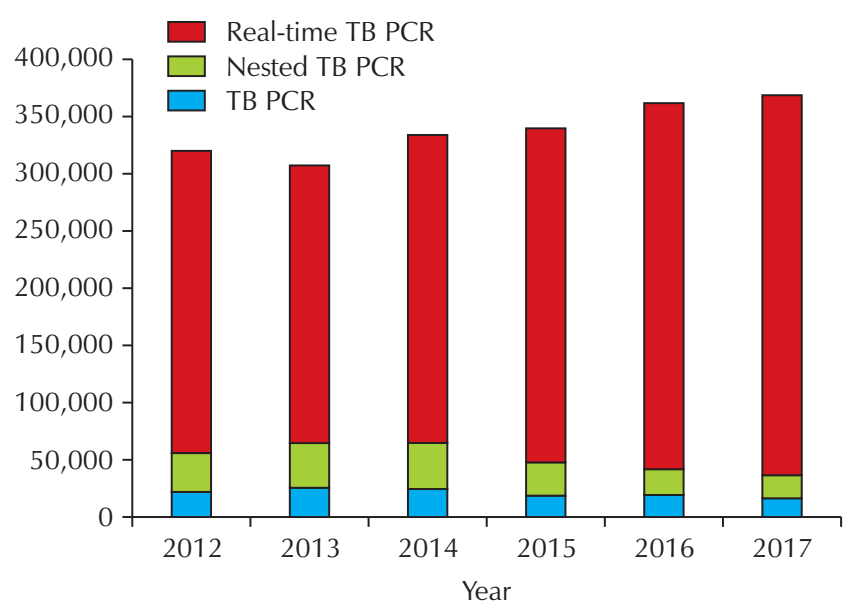

Fig. 6. Domestic molecular tuberculosis identification test scale performed in 2012-2017 ( $P=0.119)$. Abbreviations: TB, tuberculosis; PCR, polymerase chain reaction.

원에서 대다수 사용하는 분자검사키트의 종류별로 정도관 리물질을 검증함으로써 신뢰도 향상을 기대할 수 있었으며, 2019년에도 절대정량이 가능한 digital PCR의 도입을 통해 보 다 고도화할 예정이다.

신속약제 감수성검사의 경우 각 회차별 2 개씩 정도관리물 질을 제조하였으며, 모두 일치하는 결과를 보였다. 신속약제 감수성검사 외부정도관리 고도화를 위해 검사키트별 probe design 등을 고려하여 보다 다양한 유전변이에 대한 검출능 비 교와 외부정도관리 적용이 필요할 것으로 생각된다. 또한 지속 적으로 발생하는 라벨링 부착교체에 따른 부정행위를 방지하

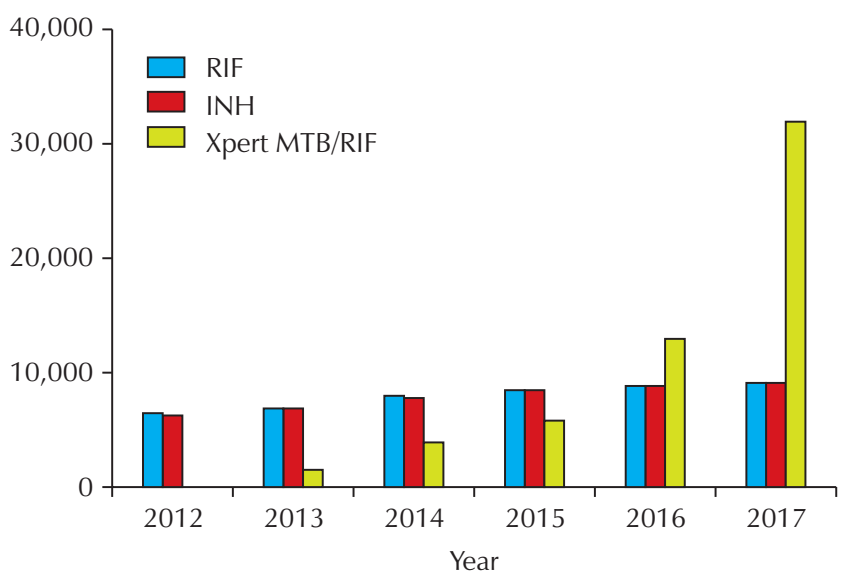

Fig. 7. Domestic rapid antitubercouls drug susceptibility test scale performed in 2012-2017 $\left(P=0.008^{*}\right)$. Abbreviations: RIF, rifampicin; INH, isoniazid; MTB, Mycobacterium tuberculosis. ${ }^{\star} P<0.05$.

기 위해 2019년도 외부정도관리 신빙도조사사업에서는 훼손 방지 스티커를 일괄 적용할 예정이다.

결핵진단검사 정도관리 신빙도조사사업은 2019년도부터 질 병관리본부의 '결핵진단검사 정도관리'사업의 지원으로만 수 행되며, 3년 과제로 보다 안정적으로 수행될 수 있을 것으로 생각되나, 연 2회로 축소 운영됨으로써 외부정도관리 성적에 따른 질 가산료 반영에 회차별, 검체별 결과 적합 여부가 보다 중요하게 적용될 것으로 예상되고, 보다 철저한 표준물질제작 및 검증 수행이 강화되어야 할 것으로 생각된다.

\section{REFERENCES}

1. World Health Organization. Global tuberculosis control 2018. Geneva: World Health Organization, 2018.

2. Korea Centers for Disease Control and Prevention. Annual report on the notified tuberculosis in Korea 2018. Cheongju: Korea Centers for Disease Control and Prevention, 2018.

3. Steingart KR, Ng V, Henry M, Hopewell PC, Ramsay A, Cunningham J, et al. Sputum processing methods to improve the sensitivity of smear microscopy for tuberculosis: a systematic review. Lancet Infect Dis 2006;6:664-74.

4. World Health Organization. Framework of indicators and targets for laboratory strengthening under the End TB Strategy. Geneva: World Health Organization, 2016.

5. Aziz M, Ba F, Becx-Bleumink M, Bretzel G, Humes R, 


\section{Journal of LABORATORY MEDICINE and QUALITY ASSURANCE}

\section{Soyoun Shin et al • Report on Clinical Mycobacteriology EQA Program}

Table 20. Status and trend of TB diagnostics test performed in 2012-2017

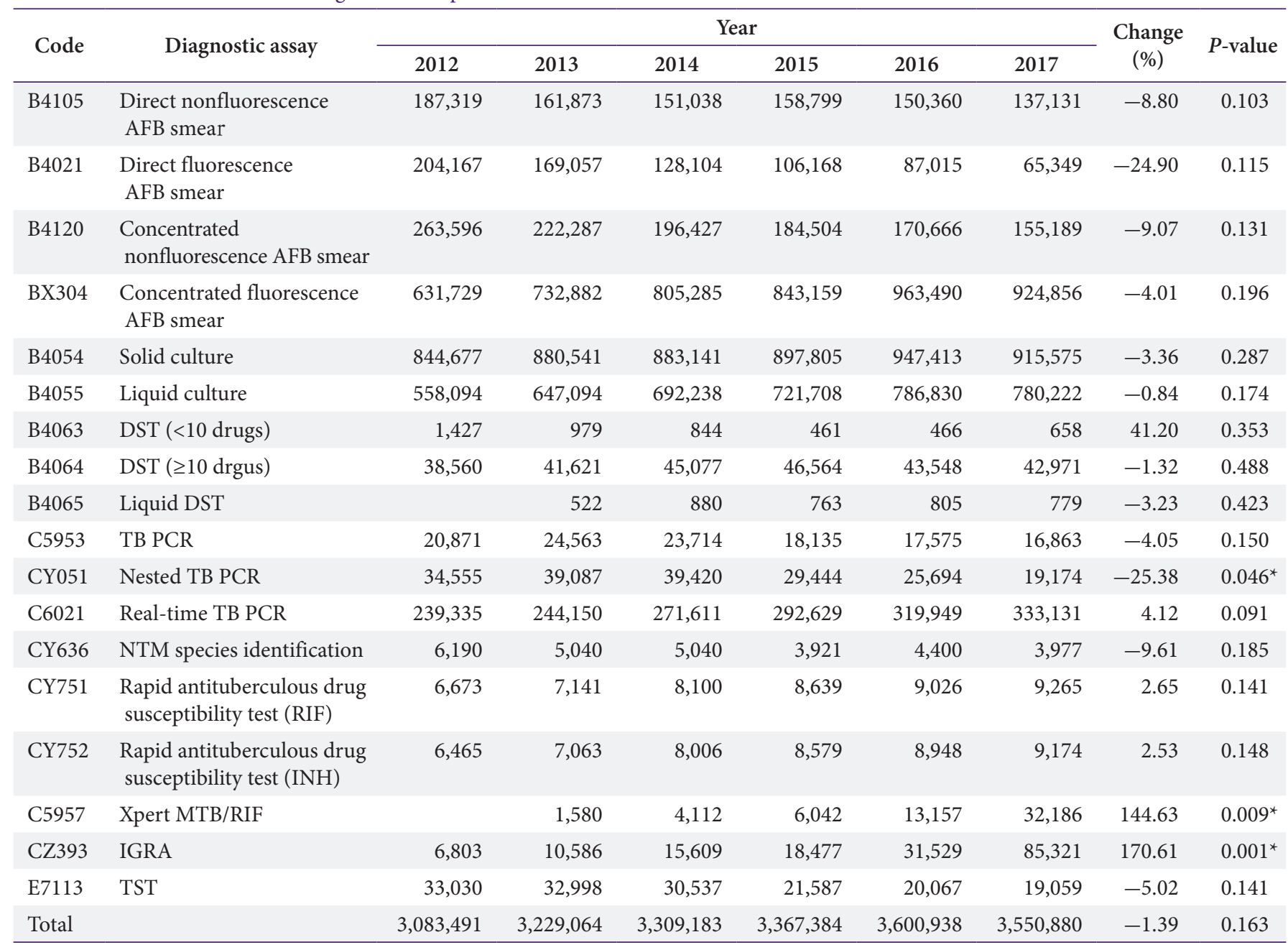

Values are presented as mean \pm standard error of mean $(\mathrm{n}=6)$.

Abbreviations: TB, tuberculosis; AFB, acid-fast bacilli; DST, drug susceptibility testing; PCR, polymerase chain reaction; NTM, nontuberculous mycobacteria; RIF, rifampicin; INH, isoniazid; MTB, Mycobacterium tuberculosis; IGRA, interferon-gamma release assay; TST, tuberculin skin test.

${ }^{\star} P<0.05$.

Ladermarco MF. External quality assessment for AFB smear microscopy. Geneva: World Health Organization, 2002.

6. Rieder HL, van Deun A, Kam KM, Kim SJ, Chonde TM, Trebucq A, et al. Priorities for tuberculosis bacteriology services in low-income countries. 2nd ed. Paris: Inter- national Union Against Tuberculosis and Lung Disease, 2007.

7. World Health Organization. Technical manual for drug susceptibility testing of medicines used in the treatment of tuberculosis. Geneva: World Health Organization, 2018. 